\title{
A Governance Analysis of Con Dao National Park, Vietnam
}

\author{
Authors: \\ Duong T Khuu*, Institute for Sustainable Resources (ISR), University College London, United Kingdom \\ Peter JS Jones, Department of Geography, University College London, United Kingdom \\ Paul Ekins, Institute for Sustainable Resources (ISR), University College London, United Kingdom \\ *Corresponding author: thuy.khuu.13@alumni.ucl.ac.uk
}

Declarations of interest: none.

\begin{abstract}
This paper examines the governance of Con Dao National Park (CDNP), through applying the marine protected area governance (MPAG) analysis framework. CDNP was one of the first protected areas in Vietnam for which biodiversity conservation was recognised as being of international importance. It is emerging in a context of increasing economic liberalisation and delegation of decision-making power to province/district-level governments, yet under the tight control of Vietnam's Communist Party. Accordingly, the governance approach that CDNP has adopted is state-led with increasing decentralisation of responsibilities to local governments, with a focus on terrestrial protected area components. Like other protected areas in Vietnam, the governance of CDNP, especially of conservation activities, has significantly benefited from international donor and NGO funding, along with technical support. Key challenges in governing CDNP include a lack of capacity for enforcement under an unclear legal framework, lack of transparency, accountability and fairness, limited coordination among local government agencies, limited community participation, harmful linkages between certain user groups and local authorities, a lack of conditions attached to property/use rights, and weak leadership. With remarkable achievements in socio-economic development over the past three decades, Vietnam arguably has sufficient capacity to adopt more effective and realistic solutions to address such challenges. However, as many of the potential solutions are contradictory to Vietnam's political direction, improving MPA governance will significantly depend on whether the Communist Party's leaders have sufficient political will to put forth conservation initiatives.
\end{abstract}

Keywords: MPAs, governance, biodiversity conservation, Vietnam, management effectiveness, decentralisation.

This is the authors' version of the final accepted Marine Policy manuscript. Elsevier $(2020$. This manuscript version is made available under the CC-BY-NC-ND 4.0 license. https://doi.org/10.1016/j.marpol.2020.103986

Duong T. Khuu, Peter JS. Jones and Paul Ekins (in press) A governance Analysis of Con Dao National Park, Vietnam. Marine Policy, 103986. https://doi.org/10.1016/j.marpol.2020.103986. One of 20 papers in a special section of 28 case studies on MPA Governance. 


\section{Introduction}

This study aims to analyse the governance of Con Dao National Park (CDNP) in Vietnam using the MPA governance (MPAG) framework [1]. It is part of the first author's PhD research on governing marine resources and biodiversity conservation in Vietnam [2] and is one of the MPAG governance case study papers presented in this special section [3]. The selection of case studies was primarily based on Vietnam's first marine biodiversity surveys of 1993-1995, in which CDNP was listed as one of Vietnam's six most important coral reefs in need of conservation [4]. Consequently, with international influence, CNDP was included in the national strategic plan for establishing Vietnam's MPA network, which comprises sixteen MPAs straddling along Vietnam's coastline [5].

Since the MPAG framework represents a grounded theory approach with a focus on analysing incentives, it highlights the need for ethnographic work to understand in-depth the typical behaviour and value priorities of different MPA user groups so that realistic and meaningful solutions to ameliorate the use conflicts, and thereby, improve governance, can be explored and biases arisen from qualitative judgements can be minimised. Various sources of data (mainly qualitative) for this study were collected during a field trip in the Con Dao archipelago from May to July 2016. These data, including extensive reviews of published and grey literature; twenty-two indepth (semi-structured/unstructured) interviews with local key MPA actors (MPA staff, local fishers, tourism operators, local government officials, etc.), and four semi-structured interviews with central government officials; and field notes produced from participant/non-participant observation, were triangulated to reduce biases and ensure trustworthiness of the research findings. The rationale and details of the MPAG methodology are discussed in detail in the introductory paper to this special section [3]. Since Vietnam's marine resources and conservation governance has been covered limitedly in international peer-reviewed literature, this article will contribute a basis to discover challenges and opportunities in governing MPAs in Vietnam and potential solutions to the recurring issues of unsustainable development and biodiversity loss in Vietnam. Although the study is case-specific with a particular focus on the marine environment, there are transferable lessons for other protected areas in Vietnam and other countries sharing similar contextual factors and challenges. These are discussed more fully in the initial paper in this special section [3], but some are discussed herein.

\section{Con Dao National Park}

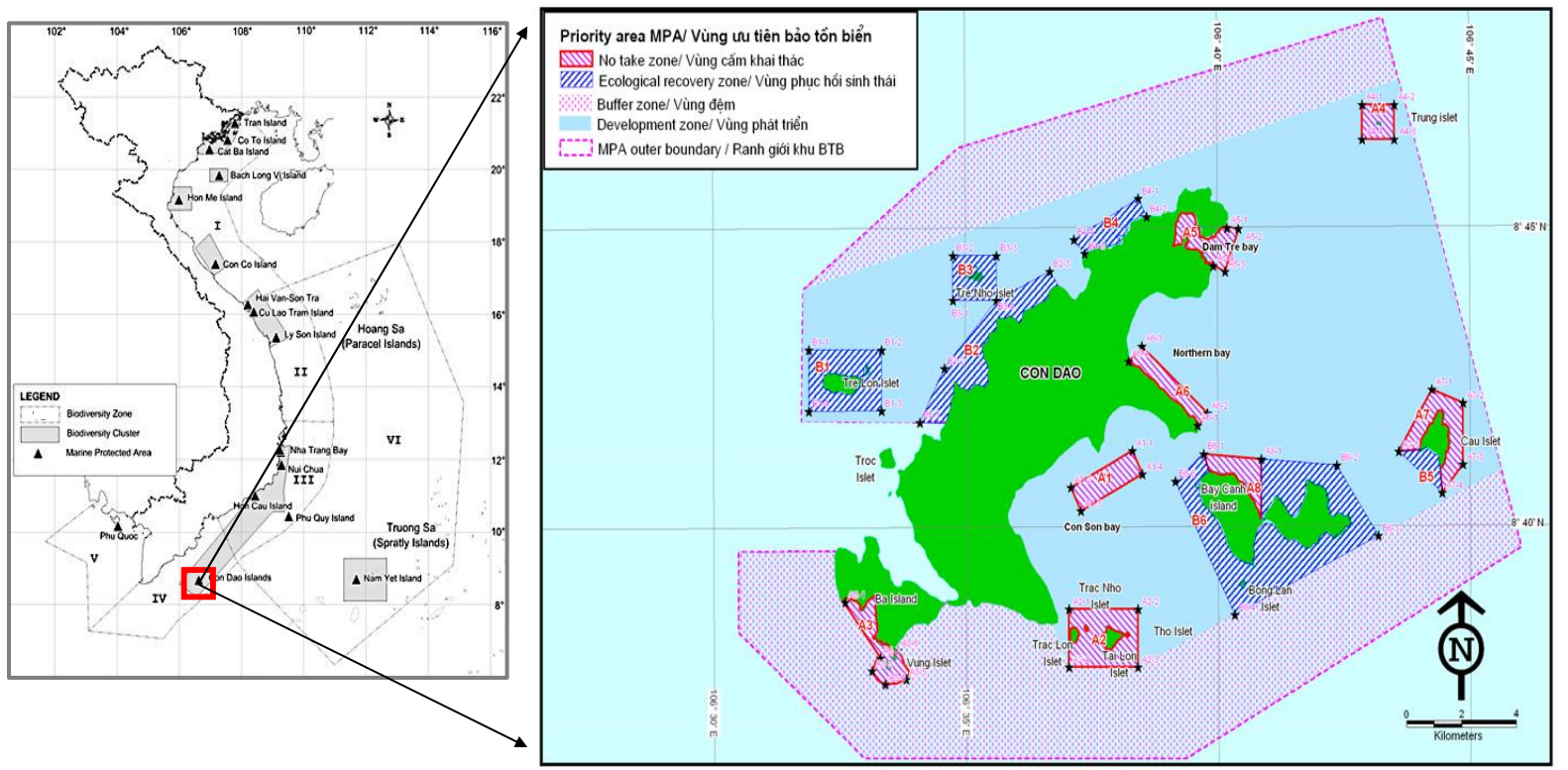

Figure 1. Location and zoning map of CDNP.

Duong T. Khuu, Peter JS. Jones and Paul Ekins (in press) A governance Analysis of Con Dao National Park, Vietnam. Marine Policy, 103986. https://doi.org/10.1016/j.marpol.2020.103986. One of 20 papers in a special section of 28 case studies on MPA Governance. 
The Con Dao archipelago lies in the South China Sea, $185 \mathrm{~km}$ from Vung Tau city of Ba Ria-Vung Tau province in South Vietnam (Fig. 1). The National Park was designated in 1993 by Ba Ria-Vung Tau Provincial People's Committee (BRVT-PPC), with an overall area of $150 \mathrm{~km}^{2}$ comprised of a $60 \mathrm{~km}^{2}$ Special Use Forest (SUF) and a 90 $\mathrm{km}^{2}$ marine area [6]. Following the first marine biodiversity surveys of 1993-1995, CNDP was listed as one of the prioritised sites for designating MPAs in the Biodiversity Action Plan for the 1996-2000 period [7]. Following that, the MPA component was expanded $140 \mathrm{~km}^{2}$ in area (i.e. $70 \%$ of the park's area) to ensure better protection of Con Dao's marine biodiversity and critical habitats [8]. The national park now embraces fourteen islands covering about $80 \%$ of Con Dao archipelago [9]. The park is centred by Con Son island, the largest island (with an area of $58 \mathrm{~km}^{2}$ ) and the only inhabited island, with about 7,000 people who reside outside the park boundaries.

Con Dao has a typical tropical climate with an average temperature of $26^{\circ} \mathrm{C}$ [10] that is ideal for tropical forest, wetland and marine habitats. The dry forest comprises 1,077 plant species including 44 endemic species that are found nowhere in Vietnam and 160 species of wild animals [11]. Shallow marine waters and wetland areas include $18 \mathrm{~km}^{2}$ of coral reefs, $10.4 \mathrm{~km}^{2}$ of seagrass beds and $0.4 \mathrm{~km}^{2}$ of mangrove forests [12]. These habitats are known as 'primitive' and support high biodiversity [13]. CDNP's coral reefs are highly diverse with 360 species of corals of the four most common types, i.e. Acropora, Pachyseris, Montipora and Pavona corals, that form nursing and breeding grounds for 202 reef fish, 116 crustaceans, 46 echinoderms, and 187mollusc species [12, $14,15]$. In 2000, Con Dao was known to have the highest densities of reef fish in Vietnam with an average of $2017 \mathrm{fish} / 500 \mathrm{~m}^{2}$. Co-existing with coral reefs are seagrass beds of eleven species (among 14 species found in Vietnam) forming the most diverse and densest seagrass meadow areas in Vietnam [12]. With such critically important habitats, CDNP has provided nursing and nesting sites for about $90 \%$ of Vietnam's sea turtle population. Green turtles (Chelonia mydas) are the most common species found nesting in CDNP with about 250 female green turtles laying eggs yearly and $80 \%$ of nests laid between June and September [16]. Hawksbill turtles (Eretmochelys imbricata), which were once abundant, are now occasionally found grazing on coral reefs. The IUCN Red List of Threatened Species classifies green turtles as endangered and hawksbill turtles as critically endangered and both are included in CITES Appendix I that lists the most endangered species among all CITESlisted species. Other endangered marine mammals found in CNDP are dugongs (Dugong dugon) (about eight to twelve dugongs living in CDNP). Also, two dolphin species - i.e. Spinner dolphins (Stenella longirostris) and bottlenose dolphin (Tursiops truncates) are sometimes observed in CDNP [17]. Due to this biological wealth, in 2013 CDNP was declared as the sixth RAMSAR site (Wetland of International Importance) of Vietnam, and the $2,203^{\text {rd }}$ RAMSAR site in the world [12], for meeting five (out of nine) criteria of the RAMSAR Convention (containing representative, rare, and unique wetland types, importance for conserving biodiversity, etc.). Therefore, the protection of Con Dao's biodiversity is of international importance.

\section{Case study context}

\subsection{National context}

Vietnam is recognised as one of the world's biodiversity hotspots in need of urgent conservation attention [18, 19]. Recognising such a potential of rich natural resources, the country launched its reform policy (widely known

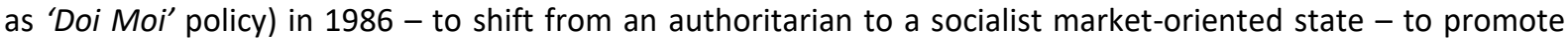
natural resource-based industrialisation and modernisation. The policy has resulted in numerous remarkable achievements, including rapid economic growth and rising per capita income (Table 1) and provided for Vietnam to become a lower-middle income country [20]. Nevertheless, the natural resource-intensive development has brought about critical environmental issues that have lifted Vietnam up in the ranks of least environmentally friendly countries (e.g. illegal wildlife trading, plastic waste inputs into the oceans, etc.) [21, 22, 23]. Such a degrading state of the environment along with commitments made by the Vietnamese government to international agendas on environmental protection and biodiversity conservation (e.g. CBD, CITES, RAMSAR, etc.) have considerably drawn attention from the international conservation community [24]. During the 1990s-2010s period, the involvement of international conservation organisations in Vietnam's biodiversity conservation increased significantly, with a particular focus on advocacy for establishing protected areas, including CDNP [2]. Concurrently, in a context of rapid economic growth and increasing decentralisation of autonomy to local authorities, on the one hand, a middle class has grown in Vietnamese society that closely relates to the state and

Duong T. Khuu, Peter JS. Jones and Paul Ekins (in press) A governance Analysis of Con Dao National Park, Vietnam. Marine Policy, 103986. https://doi.org/10.1016/j.marpol.2020.103986. One of 20 papers in a special section of 28 case studies on MPA Governance. 
depends on the state rather than challenging it in the manner of Western-style democratisation [25]. On the other hand, the increasing decentralisation with the infiltration of market forces has resulted in a powerful alliance between local decision-makers and corporations. These alliances coupled with a lack of oversight from the central government have led to power asymmetries and conditioned clientelism in protected areas decisionmaking, unsustainable resource-use patterns and associated equity issues (land reclamation for development projects, changes in access to resources, etc.) - the typical challenges in governing protected areas in developing countries $[26, \underline{27]}$.

Table 1 Basic socio-economic development metrics of Vietnam.

\begin{tabular}{|c|c|c|c|c|c|c|}
\hline $\begin{array}{l}\text { GDP per } \\
\text { capita }\end{array}$ & $\begin{array}{l}\text { GDP } \\
\text { growth } \\
\text { rate }\end{array}$ & $\begin{array}{l}\text { GDP composition } \\
\text { by sector }\end{array}$ & $\begin{array}{l}\text { State } \\
\text { capacity }\end{array}$ & $\begin{array}{l}\text { Human } \\
\text { Development } \\
\text { Index (HDI) }\end{array}$ & $\begin{array}{l}\text { Government } \\
\text { type }\end{array}$ & $\begin{array}{l}\text { Population } \\
\text { living below } \\
\text { poverty line }\end{array}$ \\
\hline $\begin{array}{l}\text { US\$ 2,343 } \\
\text { [28] (rank } \\
\text { 132/184, } \\
2017 \text { est.) }\end{array}$ & $\begin{array}{l}6.8 \% \\
(2017 \\
\text { est. })^{[28]}\end{array}$ & $\begin{array}{l}\text { Agriculture: } 16.3 \% \\
\text { Industry: } 32.7 \% \\
\text { Service: } 40.9 \%{ }^{[29]} \\
\text { (2016 est.) }\end{array}$ & $\begin{array}{l}-0.34 \\
\text { (rank } \\
41.4 \%) \\
(2016 \text { est.) } \\
{[30]}\end{array}$ & $\begin{array}{l}0.683 \text { (rank } \\
115 / 188) \\
\text { (2015 est.) }^{[31]}\end{array}$ & $\begin{array}{l}\text { Socialist } \\
\text { market- } \\
\text { oriented } \\
\text { state }\end{array}$ & $\begin{array}{l}13.5 \% \\
(2014)^{[28]}\end{array}$ \\
\hline
\end{tabular}

\subsection{Socio-economic context}

Con Dao is well-known in Vietnam as a 'sacred land' where about 20,000 nationalists died of harsh punishment and torture between 1861 and 1975 [3]. In 1861, Con Dao was in the control of the French who then set up a penal system (featured by the famous 'tiger cages') for sanctioning nationalists. The system was then taken over by the American and the South Vietnam government in 1954 and shut down after the reunification of 1975 [32], when Con Dao only had 2,000 residents comprising people rooted from traditional island communities and those linked to the military and government agencies, and ex-prisoners [33]. Following Doi Moi in 1991, Con Dao district came under the administration of a brand-new Ba Ria-Vung Tau province, leading to the constant influxes of migrants from the mainland. Now the average population growth rate is about 6\% per annum and Con Dao's population size is poised to increase from its current 7,000 to 50,000 people by 2020 [34]. Of Con Dao's current population, about $60 \%$ work in public sector, $20 \%$ are the farmers and $17 \%$ are engaged in small business and trading, fishers representing only $3 \%$ of residents [17]. Annual income per capita is US\$3,600, i.e. 1.5 times higher than that of the country, this difference mainly being due to income from tourism and from public sector employment because officials are offered 50\% higher salary compared to working on the mainland [2]. The annual GDP growth rate of Con Dao is 13\% (two times the national GDP) with $87 \%$ of GDP contributed by tourism and services, $8 \%$ by industry and $5 \%$ by agriculture-forestry-fisheries [35]. Unlike other districts in Vietnam, Con Dao district has no commune/ward level. Con Dao residents disperse in nine self-governed groups that are directly managed by Con Dao District People's Committee (CD-DPC). The social welfare of Con Dao residents is supported by various channels of CD-DPC, e.g. poverty reduction fund, the micro-credit scheme of the bank of social policies, and the provision of agriculture seedlings and training courses in tourism [2].

\section{Objectives}

The daily management of CDNP is being guided by 'a master plan for the development of Con Dao National Park 2009-2020' (conservation and operational objectives are laid out in Table 2 [36]) with a focus on capacity for forest protection. For the MPA component, management focuses on the protection of coral reefs, seagrass beds, and endangered species, including green turtles, giant clams, dugongs, and giant top-shell [37]. MPA management is implemented through the zoning regulations [17] (Fig. 1).

Duong T. Khuu, Peter JS. Jones and Paul Ekins (in press) A governance Analysis of Con Dao National Park, Vietnam. Marine Policy, 103986. https://doi.org/10.1016/j.marpol.2020.103986. One of 20 papers in a special section of 28 case studies on MPA Governance. 
Table 2 Objectives and related management actions for CDNP (adapted from [36]).

\begin{tabular}{|l|l|l|}
\hline \multicolumn{1}{|c|}{ Conservation Objectives } & \multicolumn{1}{c|}{ Operational Objective } \\
\hline$>$ 'To conserve the biodiversity, natural & $>$ Forest fire protection \\
landscapes, and to promote the values of CDNP & $>$ Restoration of forest and marine ecosystems \\
to enable it to function as a Special Use Forest & $>$ Scientific research: Construction of a botanic \\
per Law on Forest Protection and Development & garden and a research centre for mangrove forest \\
2004 and Biodiversity Law 2008, contributing to & and coastal wetland ecosystems \\
develop Con Dao as a site for tourism and & $>$ Development of ecotourism programmes \\
services especially ecotourism, of high & $>$ Education and awareness raising on forest, \\
standards, of national and international & environment and natural resource conservation \\
importance, serving the socio-economic & $>$ Supporting livelihood development for the local \\
development of Con Dao district guided by & $>$ communities \\
Decision 264/2005/QD-TTg dated 25 October & $>$ Capacity-building for human resources \\
2005 by the Prime Minister' & $>$ Development of Park's infrastructure and facilities \\
\hline
\end{tabular}

\section{Drivers/conflicts}

The tourism sector of Con Dao is projected to thrive in the next ten to twenty years [38]. Also, the central government has encouraged more developments in Con Dao by providing developers and investors with attractive incentives (tax reductions, land lease fee reductions, using of ODA capital and preferential credit to develop infrastructures, etc.) [39]. Therefore, tourism impacts are arguably the primary threats to CDNP conservation objectives. Although the agriculture sector (including fisheries) contributes over $5 \%$ of Con Dao's GDP, the impacts of fisheries are significant and largely unknown due to a lack of effective fisheries data collection, monitoring and management measures. Other threats to CDNP's conservation objectives are sea turtle poaching and trading, climate change and water pollution.

\subsection{Tourism development}

During the 2000-2015 period, the number of tourists visiting Con Dao increased from 15,000 to 135,000 per year (nine-fold) (Fig. 2), with 38 resorts and hotels now on Con Son island [12]. Tourism in Con Dao is seasonal because about $45 \%$ of tourist visits are between May and July when travelling by boats and flights becomes more accessible. About $80 \%$ of the tourists are domestic. They mostly visit Con Dao for its cultural and historical values, including Hang Duong cemetery and the tiger cage Prisoner of War system. With only $19 \%$ of tourists to Vietnam (both domestic and foreign tourists) having visited CDNP in 2015 [12], Con Dao District People's Committee (CD-DPC) regarded the island's tourism sector as 'underdeveloped' and put forth a strategic development plan for Con Dao towards 2020 - which was drafted with no Environmental Impact Assessment (EIA) but immediately approved by the central government $[10,34]$. The plan particularly set out to increase the total population to 50,000 people and the number of tourists to $200,000-250,000$ tourist visits per year by 2020 , with diversifying tourism products and developing more infrastructure at the epicentre of this plan.

Regarding tourism activities within CDNP, before June 2015, CDNP Authority was the biggest ecotourism operator (among a few private tourism operators) that provided tours to CDNP's different attractions. The park authority had also generated income from park entrance and user fees to fund its conservation activities. However, due to conflicts arisen in park management (including fraudulent fee collection and management processes driven by internal power conflicts and rent-seeking behaviour) and between CNDP and the district government, the park authority has been suspended from user fee collection and tourism operations.

Duong T. Khuu, Peter JS. Jones and Paul Ekins (in press) A governance Analysis of Con Dao National Park, Vietnam. Marine Policy, 103986. https://doi.org/10.1016/j.marpol.2020.103986. One of 20 papers in a special section of 28 case studies on MPA Governance. 

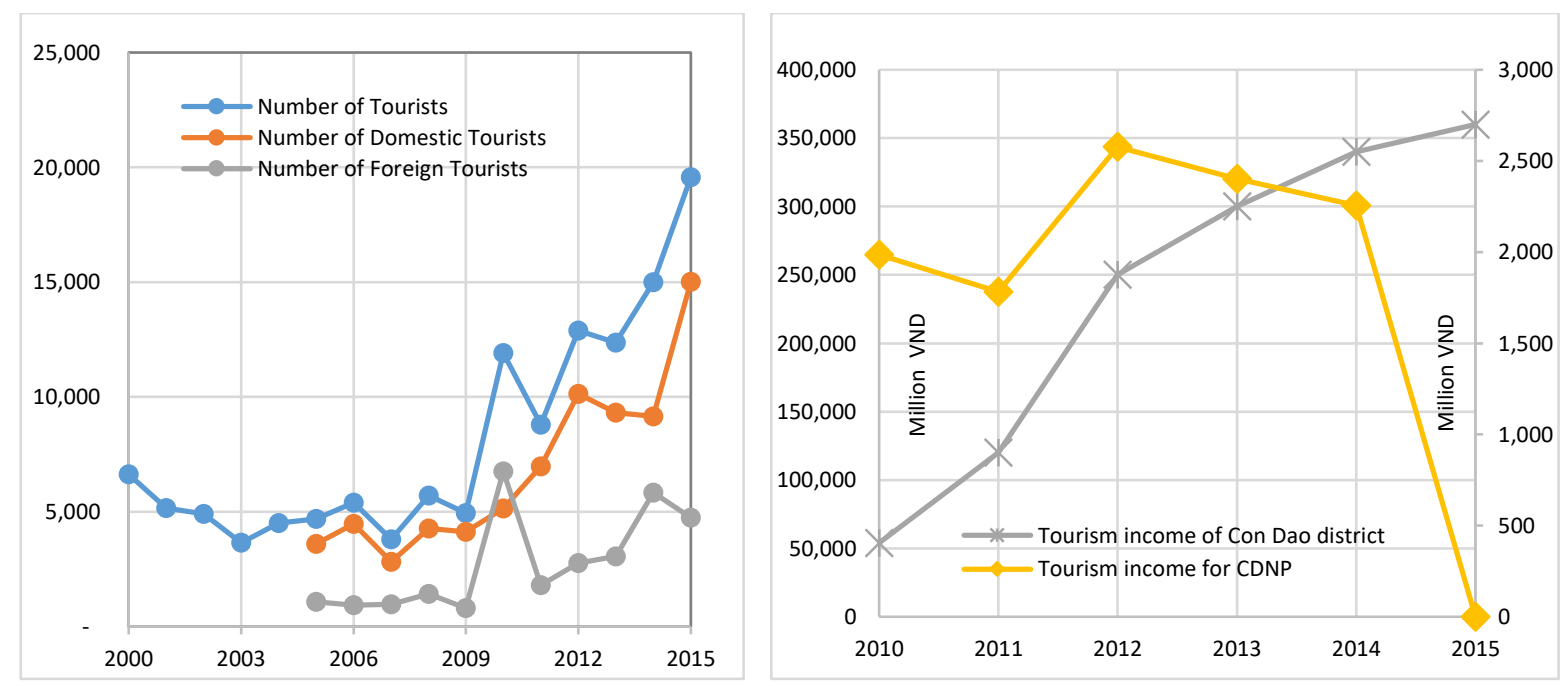

Figure 2. Number of tourists arrived in CDNP and income generated from tourism for Con Dao district and CDNP. *Note: income for CDNP went down to zero in 2015 as authority banned from collecting user fees and running tourism operations, whilst income to local communities will have been highest in 2015 (Source: [12]).

Compared to other protected areas in Vietnam, tourism activities in CDNP are less intense due to its remote location and high costs of travelling. Nonetheless, like other tourist destinations, tourism in Con Dao is poorly controlled. The number of tourist boats is currently low but has increased rapidly in the past decade. There are about 20 speedboats of $11-27$ guest capacity, and eight wooden motorised boats of $12-30$ guest capacity [12] taking tourists from Con Son to other islands. Tourist boats often anchor on reefs although mooring buoys were installed, sewage is directly discharged into the sea, speedboat noise has disturbed dugongs, etc. With only three dive operators, scuba diving in Con Dao is less popular than other MPAs in Vietnam.

\subsection{Small-scale fisheries}

Con Dao fishers employ small-scale fishing methods, including hookah diving, hand-lining for cuttlefish, using single-layered gillnets and three-layer driftnets, and longlining for tuna [17]. Among these methods, cyanide fishing was considered by CDNP Authority as more common and more detrimental to the park's conservation features. Cyanide fishing was introduced to Con Dao about 20 years ago when local fishers engaged in live grouper trading with Hong Kong dealers. In recent years, owing to the increasing demand for local seafood and dwindling nearshore fish stocks, diving fishers from neighbouring provinces have migrated to Con Dao for better income opportunities. Although cyanide fishing is strictly prohibited by the national Law on Fisheries, and its target species (spiny lobsters, groupers, moray eels, etc.) are protected by CDNP regulations, because of a tradition of rule-breaking in Vietnam and high return of trade, fishers tend to ignore the illegality of their activities. Besides cyanide fishing, a sharp increase in the number of offshore fishing boats, which often employ damaging methods like bottom trawling and purse sein with strong lights of over 2000Watts, has increasingly threatened CDNP's conservation features. The opening of Ben Dam port in 2001, a fishing and service centre that can accommodate vessels of 2000 DWT [12], was one of the main causes of this expansion. These boats often dock at Ben Dam where they unload their catch and recharge with fuel and ice. Between 2004 and 2005, about 6,000 to 7,000 offshore fishing boats anchored in Ben Dam port [40] and the number has increased recently because of displacement of fishing efforts driven by the nationwide depletion of fish stocks. Under such circumstances, local fisheries statistics are lacking and unreliable. Data from offshore fishing boats, catch from angling, spear fishing in coral reefs by tourists and gleaning of limpets and cockles in rocky shores by local people are frequently neglected by Con Dao district government. Therefore, the environmental impacts of fishing on CDNP's conservation targets remain inadequately understood.

Duong T. Khuu, Peter JS. Jones and Paul Ekins (in press) A governance Analysis of Con Dao National Park, Vietnam. Marine Policy, 103986. https://doi.org/10.1016/j.marpol.2020.103986. One of 20 papers in a special section of 28 case studies on MPA Governance. 


\subsection{Exploitation of endangered species}

Hunting sea turtles for food and handicrafts has long existed as a custom in Con Dao [41]. Since the 1990s, with funding and technical support from WWF, CDNP has integrated sea turtle conservation into its management to primarily protect them from localised exploitation and consumption. Concurrently, in the mid-1990s, after Vietnam signed several important international treaties (CBD, CITES, etc.), more legislation has been enacted to protect endangered species, including sea turtles. However, as Vietnam's economy has developed rapidly, Vietnamese society has grown a middle-class with a desire for more affluent lifestyles among which, paradoxically, consuming the most endangered and protected animals is a way of showing one's economic power and social status. As such, since sea turtles became protected species, their products, including meats and eggs, have been increasingly sought after by tourists, thus, highly priced in local black markets. Hence, the number of poachers (both locals and non-locals) has increased dramatically. Many of them switched from cyanide fishing to turtle poaching due to its high profitability and low investment costs because of the limited availability of diving boats and equipment. Despite the growing number of laws, penalising such wildlife crimes has been historically ineffective owing to a lack of awareness of protecting endangered species at all institutional levels, and a lack of political will from the higher government levels in prosecuting criminals. Also, at a site level, the large and widely dispersed nesting beaches in CDNP have limited the effectiveness of patrols for law enforcement.

\subsection{Impacts of 'Mainlandisation'}

The development of infrastructure (tourist port, fishing port, airport, ring road, etc.) has escalated the incoming pressures from tourism and fishing on CDNP's conservation objectives. Con Dao's population has grown dramatically since the 1990s. Most residents are migrants from the mainland with no Con Dao origin. Therefore, such 'mainlandisation' has resulted in the influx of communities that have none of the stewardship values for local resources that often typify island communities [42]. Moreover, given that about 60\% of Con Dao's population works in the public sector, decision-making at the district-level is largely based on the maximisation of resource use and accumulation of personal wealth for some political elites, with little concern for the environment. This is well illustrated by the district's strategic development plan and the means employed by Con Dao district government to implement it [2].

\subsection{Wider-scale impacts}

The most notable wider-scale impacts on CDNP's objectives are climate change and seawater pollution. Among all Vietnam's MPAs, CNDP is the closest to the Indo-Pacific region, in which the biggest El Nino of 1997-1998 caused the bleaching of about $80 \%$ of the region's coral reefs. CDNP is thus among the most susceptible protected areas to climate change impacts [43]. Besides, although land-based use impacts are insignificant, CDNP has been significantly affected by pollution from the Mekong River. Furthermore, as the number of tourists is increasing, and Con Dao population is expanding, the current system of waste and sewage management (e.g. landfilling solid waste and direct discharge of sewage into the sea) is putting Con Dao at risk of biodiversity loss. Meanwhile, CDNP has been increasingly facing the issues of drifting garbage discharged from offshore fishing boats and oil spills from boats and oil exploration and production plants in Vung Tau city. Given the intensifying impacts from local and surrounding uses, it is essential to sustain and improve the MPA governance incentives to reinforce CDNP's ecosystem resilience to these wide-scale impacts.

\section{Governance framework}

The governance framework of CDNP can be described as government-led but tending towards decentralisation [1]. The key stakeholders involved in governing CDNP are tourism developers, tourism operators, dive operators, local fishers, incoming fishers, CDNP Authority and its Forest Protection Unit (FPU), Ba Ria-Vung Tau Provincial People's Committee (BRVT-PPC), Con Dao District People's Committee (CD-DPC) and agencies under its belts (e.g. Fisheries Resource Surveillance Unit - FRSU, the border guard, etc.), and NGOs (Fig. 3).

Duong T. Khuu, Peter JS. Jones and Paul Ekins (in press) A governance Analysis of Con Dao National Park, Vietnam. Marine Policy, 103986. https://doi.org/10.1016/j.marpol.2020.103986. One of 20 papers in a special section of 28 case studies on MPA Governance. 
Vietnam is a centralised communist state that is in a transition towards a market-oriented communist state through continuously decentralising state management responsibilities to provincial/district governments and allowing market forces to penetrate every level of the state hierarchy. In the past, CDNP was declared as a protected forest by the central government and governed by a top-down regime in which the Ministry of Forestry (now known as the Ministry of Agriculture and Rural Development - MARD) decided on CDNP's management and development. However, following the trend towards decentralisation reforms, localities have gained more autonomy in decision-making over natural resource uses and development while the central government has confined its role to reviewing and approving long-term socio-economic development plans for provinces and municipalities under the tight supervision of the Vietnamese Communist Party (VCP) to make sure that such plans are in alignment with the VCP's direction, i.e. political stability. Based on the Law on Forest Protection and Development of 1991 [44], CDNP Authority was institutionalised as an administrative unit under BRVT-PPC to undertake daily management and enforcement functions over its terrestrial, wetland and marine areas. However, due to a lack of knowledge and regulations for managing marine areas, the MPA functioned as a paper park because CDNP Authority was much more focused on the management of Special Use Forest (SUF: a strictly protected type of forests), which was still challenged by a lack of capacity for forest protection. Only since a massive coral death event caused by the first global El Nino event of 1997-1998, followed by the increased international attention to Vietnam's biodiversity, has the concern extended to the seas, with financial and technical support from development agencies and NGOs. 


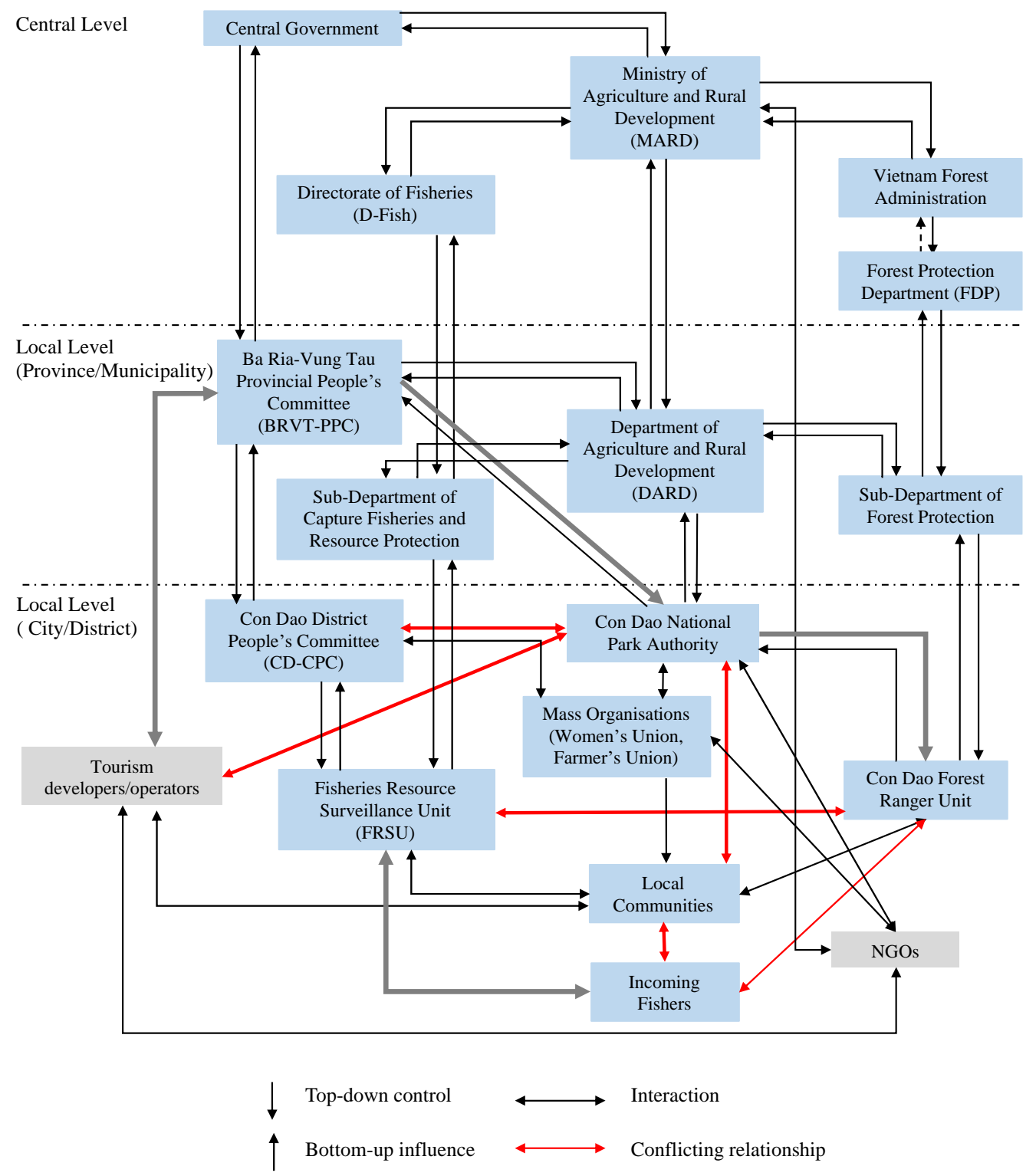

(Bold arrows present strong interations)

Figure 3. Governance framework of CDNP.

Subsequently, during the 1998-2009 period, CDNP was the focus of many donor-funded projects that helped the park to enhance its management and enforcement capacity, provided it with basic equipment, and advocated for using participative structures in MPA management. Also, at a national level, with donor support, the legal framework governing protected areas has also been improved significantly. At present, the protected forest component of CDNP is primarily governed by the new Law on Forest Protection and Development 2004, under which MARD oversees the national forest system, and its Forest Protection Department (FPD) is tasked with enforcement and forest inventory [45]. At a local level, BRVT-PPC oversees the management of protected forests within its geographical jurisdiction. The provincial agency of MARD, including the Department of Agricultural and Rural Development (DARD) and its Sub-Department of Forest Protection, oversees the enforcement of the Forest Protection and Development Law and forest inventory. At a site level, forest patrolling is undertaken by 70 forest rangers under the administration of CDNP Authority and technical supervision of DARD. Meanwhile, Con Dao's sea, including the MPA component of CDNP, is governed by the Fisheries Law of 2003, according to which enforcement responsibilities are assigned to the Fisheries Resources Surveillance Unit

Duong T. Khuu, Peter JS. Jones and Paul Ekins (in press) A governance Analysis of Con Dao National Park, Vietnam. Marine Policy, 103986. https://doi.org/10.1016/j.marpol.2020.103986. One of 20 papers in a special section of 28 case studies on MPA Governance. 
(FRSU, comprising about ten fisheries inspectors) that is administratively under Con Dao District People's Committee (CD-DPC) and technically under DARD. It is also assumed that the border guard should assist the FRSU and CDNP Authority in sea patrolling where necessary. However, in reality, the enforcement of the Fisheries Law of 2003 in CDNP is primarily undertaken by the park rangers with a lack of coordination from other agencies. This is mainly driven by the conflicts between CD-DPC and CDNPA Authority over land-use planning for socio-economic development that have resulted in the unwillingness of CD-DPC in assigning relevant people under its jurisdiction (fisheries inspectors, the Border Guard) in joint enforcement with park rangers, leading to poor coordination between these forces and ineffective law enforcement. Concurrently, the conflicts between the CDNP Authority and tourism operators/developments play out daily. Although CDNP was designated as a RAMSAR wetland site in 2013, for which management responsibilities are with the Ministry of Natural Resources and Environment (MONRE), at present, the implementation of RAMSAR, as well as the involvement of MONRE, in governing CDNP has been minor.

At the MPA designation stage, the small Con Dao communities considered themselves as not being significantly influenced by zoning regulations. After influxes of migrants, the new communities have perceived governance to be a strictly top-down obligation and their view is largely that the Park was set up to promote tourism. Community participation in CDNP's governance was only encouraged by the UNDP/GEF project during the 20062009 project period. In particular, a Community Consultation Group (CCG), comprising local government officials, village heads, and representatives from mass organisations, was formed as a collaborative structure to facilitate community consultation. However, like other donor funding MPA projects, such structures were abandoned after the donor funding ended.

\section{Effectiveness}

Based on the MPAG effectiveness scale [1], the effectiveness of CDNP in reducing impacts to achieve its conservation objectives is around the score band 1 - i.e. some impacts are beginning to be addressed. This section justifies the effectiveness of CDNP in achieving its conservation objectives against the impacts identified in Section 4.

\subsection{Protection of endangered species}

Although sea turtle surveys by scientists previously showed an annual increase in the number of turtle nests from 1999 to 2012 [46], interviews with local communities indicate recent declines in sea turtle populations with the disappearance of adult turtles in some nesting beaches. The decreasing trend can be explained firstly by the shortage of funding because since the end of donor and NGO funding in 2012, efforts in sea turtle conservation have been reduced significantly, especially in awareness-raising and monitoring of adult turtles (e.g. tagging, measuring, satellite tracking, etc.). Secondly, in enforcement, Rangers' efforts and passion in protecting turtles have been contested by a lack of rewards for their hard work and poor coordination among relevant agencies, especially insufficient political will from the CD-DPC in prosecuting the poachers, partly driven by the conflicts between CDNP Authority and fee misappropriation behaviours. As such, sea turtle meats and eggs are widely sold across all seventeen seafood restaurants on Con Dao. Many tourists bring turtle products back home via airways in ignorance of the largely unenforced restrictions by the local airport corporation and authority on exporting turtle products from Con Dao. This represents another weakness in cross-jurisdictional coordination in combating wildlife trade and a lack of awareness and political will from local authorities. Because of the increasing demand for sea turtles from tourism development and the lucrative nature of turtle poaching, poachers in Con Dao have grown in number and skills. As CDNP has focused its resources on patrolling in the nesting beaches, poachers have become more alert and have found new ways to hunt (e.g. forming partnerships with local authorities or park rangers). As such, rescuing and protecting turtle nests in the context of a lack of scientific monitoring, of capacity for enforcement, of judicial capacity for prosecution and penalisation, and of public awareness and engagement, coupled with a tendency towards fee misappropriation, have undermined the efforts for protecting adult turtles and their nests. Given that turtle conservation is a primary focus of CDNP Authority, this issue needs to be addressed urgently.

\subsection{Protection against fishing impacts}

Duong T. Khuu, Peter JS. Jones and Paul Ekins (in press) A governance Analysis of Con Dao National Park, Vietnam. Marine Policy, 103986. https://doi.org/10.1016/j.marpol.2020.103986. One of 20 papers in a special section of 28 case studies on MPA Governance. 
After the massive coral death caused by Lynda Typhoon in 1997 followed by El Nino in 1998, coral reefs and densities of fish in CDNP recovered quickly. This was partially due to the resilience of CDNP's ecosystems as they had been supported by a sound legal basis and sufficient state funding [14, 47]. Also, the UNDP/GEF project reported the stable or increasing trend of live coral cover in most areas between 2006 and 2009. However, key species populations had severely declined, especially giant clams and spiny lobsters, compared to the baseline surveys of 1993-1995 [48]. Since all sources of donor funding ended, coral reef surveys have been conducted yearly by CDNP staff following the Reef-Check protocol at permanent locations set by baseline surveys. The surveys showed as of 2015 that both coral and seagrass coverage were in a stable state, though densities of top predators decreased. In particular, the density of groupers of over $30 \mathrm{~cm}$ length was low $\left(0.3-0.49 \mathrm{fish} / 100 \mathrm{~m}^{2}\right)$ whilst moray eels and hump-head wrasse had disappeared by 2015. In contrast, herbivorous fish (snappers, parrot fish, and rabbitfish, etc.) populations are at a high density [43]. The decline in fish biomass has also been noticed by both fishers and dive instructors, especially declining populations of highly traded species such as large groupers and spiny lobsters. The increase in herbivorous fish and decrease in top predators of coral reef ecosystems is indicative of 'fishing down the food web' and the gradual removal of top-down control on ecosystems and its consequence of trophic cascade that needs to be addressed for ensuring the resilience of these coral ecosystems [49, 50]. In enforcement, due to the focus of expertise and enforcement capacity on forest and sea turtle protection, the MPA component of CDNP is loosely controlled. With the currently increasing number and adverse manner of turtle poachers and incoming fishers, effective enforcement is often perceived as an impossible task by the rangers.

\subsection{Protection against tourism impacts}

The operation of CDNP has been sustained by economic incentives, especially state and NGO funding and income generated from user fees and the provision of ecotourism services. However, in a transitional economy, the channelling of such funds from the central to local levels and vice versa endures a significant degree of rentseeking, while MPA benefits have been largely reaped by tourism operators/developers and incoming fishers. As such, the funding for conservation has long been considered as being insufficient by decision-makers, who paradoxically tend to suggest international cooperation and support as one of the potential solutions to Vietnam's MPA financial problems, rather than focusing on addressing the institutional weaknesses and addressing the issues of unsustainable tourism practices. Thus, at a site level, although priorities and concessions were given to local communities to operate tourism within CDNP, with no environmental standards attached to such rights, local communities have frequently breached the regulations to satisfy tourists' demands. Furthermore, rangers do not respect MPA regulations either as they often fish in CNDP's NTZs when adverse weather conditions disrupt their food supply by vessels. The ignorance of regulations by both local people and enforcers has resulted in the limited recognition of MPA restrictions by tourists. Consequently, tourists openly collect clams, sea cucumber and coral specimens, and trample on corals. It is not the only problem of the Park, but also a problem of weak implementation and outreach of national laws on environmental protection and natural resource management.

\section{Incentives}

The incentives applied to the governance of CDNP and needed to improve the governance framework are summarised in Table 3.

Table 3 Summary of Incentives applied $(Y)$ including those that are particularly important priorities for strengthening $\left(\mathrm{Y}^{*}\right)$ and introducing $\left(\mathrm{N}^{*}\right)$ (a more detailed table is provided in Supplementary Material).

\begin{tabular}{|c|l|c|l|}
\hline No & \multicolumn{1}{|c|}{ Incentive } & Used & \multicolumn{1}{c|}{ How/Why } \\
\hline \multicolumn{2}{|c|}{ Economic } & $\mathrm{N}^{*}$ & $\begin{array}{l}\text { Because of the unjust sharing of costs and benefits, PESs (e.g. Blue carbon) is worth } \\
\text { considering. Nonetheless, Vietnam's immature regulatory framework could make this } \\
\text { incentive ineffective at a CDNP operational level due to the risk of rent seeking and fund } \\
\text { appropriation at higher levels. }\end{array}$ \\
\hline 1 & $\begin{array}{l}\text { Payment for Ecosystem } \\
\text { Services (PESs) }\end{array}$ & \\
\hline
\end{tabular}

Duong T. Khuu, Peter JS. Jones and Paul Ekins (in press) A governance Analysis of Con Dao National Park, Vietnam. Marine Policy, 103986. https://doi.org/10.1016/j.marpol.2020.103986. One of 20 papers in a special section of 28 case studies on MPA Governance. 


\begin{tabular}{|c|c|c|c|}
\hline 3 & $\begin{array}{l}\text { Reducing the leakage of } \\
\text { benefits }\end{array}$ & $\mathrm{Y}^{*}$ & $\begin{array}{l}\text { CDNP Authority granted concession to local boats to operate ecotourism in CDNP, but these } \\
\text { boats often breach the park regulations, particularly given the lack of enforcement capacity (I- } \\
18 \text { below). }\end{array}$ \\
\hline 4 & $\begin{array}{l}\text { Promoting profitable and } \\
\text { sustainable fishing and } \\
\text { tourism }\end{array}$ & $\mathrm{Y}^{*}$ & $\begin{array}{l}\text { Although the zoning regulations exist for restricting unsustainable fishing and tourism } \\
\text { activities, violations in both fisheries and tourism occur daily and the situation is tolerated by } \\
\text { CDNP Authority because the park has insufficient capacity for controlling the impacts of fishing } \\
\text { and tourism. }\end{array}$ \\
\hline 5 & Promoting green marketing & $\mathrm{Y}^{*}$ & $\begin{array}{l}\text { Despite a cap of tourist numbers is adopted for sea turtle observation, this strict limit is } \\
\text { employed to market CDNP's turtle observation tours as 'eco' making them a flagship for } \\
\text { ecotourism in CDNP. The cap is often exceeded and tourists' bad behaviours that are } \\
\text { tolerated by the rangers. }\end{array}$ \\
\hline 6 & $\begin{array}{l}\text { Promoting diversified and } \\
\text { supplementary livelihoods }\end{array}$ & $\mathrm{Y}^{*}$ & $\begin{array}{l}\text { The UNDP/GEF project attempted several Alternative Income Generation (AIG) activities } \\
\text { (seaweed farming, boat upgrading, etc.) most of which are no longer viable due to unrealistic } \\
\text { designs and short-term funding and technical support. }\end{array}$ \\
\hline 9 & Provision of state funding & $\mathrm{Y}^{*}$ & $\begin{array}{l}\text { CDNP is principally financed by state funding (US\$500,000 per year) that is allocated to staff } \\
\text { salaries, infrastructure and utility costs. The provincial government funds the park's daily } \\
\text { management (patrolling: US\$60,000/ year, scientific research and monitoring: } \\
\text { US } \$ 100,000 / \text { year, etc.). Other sources include funding from donors. More funding is needed } \\
\text { for more sea patrols and regular monitoring. }\end{array}$ \\
\hline 10 & $\begin{array}{l}\text { Provision of NGO, private } \\
\text { sector and user fee funding }\end{array}$ & $\mathrm{Y}^{*}$ & $\begin{array}{l}\text { NGO funding was mostly invested in scientific research and monitoring of sea turtles, } \\
\text { purchasing of equipment and raising public awareness. After all sources of NGO funding ended } \\
\text { in } 2012 \text {, such activities have been continued by the income generated from tourist user fees, } \\
\text { which has been disrupted recently, as, the park authority has been suspended from user fee } \\
\text { collection and tourism operations, leading to the shortage of funding to continue such } \\
\text { activities. }\end{array}$ \\
\hline \multicolumn{4}{|c|}{ Interpretative } \\
\hline 11 & Raising awareness & $\mathrm{Y}^{*}$ & $\begin{array}{l}\text { Information on CDNP's protected species was communicated using booklets and brochures. } \\
\text { Awareness-raising sessions were held in residential areas, on fishing boats, and among the } \\
\text { Army personnel based on Con Dao. However, now these activities are irregular due to the } \\
\text { shortage of funding. Short-term NGO-funded projects in environmental education have not } \\
\text { provided any significant long-term impacts and there has recently been very little awareness- } \\
\text { raising efforts. }\end{array}$ \\
\hline 12 & $\begin{array}{l}\text { Promoting recognition of } \\
\text { benefits }\end{array}$ & $\mathrm{Y}$ & $\begin{array}{l}\text { Potential benefits of protecting the target resources through fish spillover/export, tourism, } \\
\text { etc. have been promoted through awareness-raising sessions and community capacity building } \\
\text { programmes. However, this incentive is undermined by the recent neglect of such activities } \\
\text { coupled with ineffective enforcement, weak coordination and a lack of community } \\
\text { stewardship. Currently, since no conservation benefits are noticeable, it is unnecessary to } \\
\text { strengthen this incentive, instead focus the capacity on enhancing the incentives that support } \\
\text { it, i.e. the capacity for enforcement (I-18), penalties for deterrence, etc. }\end{array}$ \\
\hline 13 & $\begin{array}{l}\text { Promoting recognition of } \\
\text { regulations and restrictions }\end{array}$ & $\mathrm{Y}^{*}$ & $\begin{array}{l}\text { Signboards were erected in some residential areas and ranger stations to inform the public } \\
\text { about zoning regulations and restrictions. Banners, posters, and signboards were also used to } \\
\text { communicate the illegality and penalisation of hunting and trading sea turtles. Nonetheless, } \\
\text { CNDP regulations and restrictions are regularly ignored in reality, despite being widely } \\
\text { recognised. }\end{array}$ \\
\hline \multicolumn{4}{|c|}{ Knowledge } \\
\hline 14 & Promoting collective learning & $\mathrm{Y}^{*}$ & $\begin{array}{l}\text { Working alongside marine ecologists in donor-funded biodiversity assessments has enhanced } \\
\text { the capacity of park rangers in marine conservation and management. The UNDP/GEF project } \\
\text { also helped to build capacity for local fishers in scuba diving and coral rehabilitation. Currently, } \\
\text { due to a shortage of funding for regular coral reef monitoring, it could be cost-effective to } \\
\text { promote collaboration with the international dive operators and local diving fishers. }\end{array}$ \\
\hline \multicolumn{4}{|c|}{ Legal } \\
\hline 17 & Hierarchical obligations & $\mathrm{Y}^{*}$ & $\begin{array}{l}\text { International legal obligations applicable to CDNP include those under the CBD, CITES and } \\
\text { RAMSAR convention. Several national laws also support the enforcement of park regulations } \\
\text { However, the ambiguous legal framework has challenged the effective management of CDNP. }\end{array}$ \\
\hline 18 & Capacity for enforcement & $\mathrm{Y}^{*}$ & $\begin{array}{l}\text { Compared to other MPAs in Vietnam's MPA network, CDNP has higher capacity for } \\
\text { enforcement because of the 'National Park' designation and higher advocacy capacity of the } \\
\text { park's former leadership. Rangers are empowered to impose certain kinds of administrative } \\
\text { sanctions on MPA violators. However, due to the scattering of turtle nesting beaches, } \\
\text { enforcement capacity is still insufficient, especially in protecting the NTZs from cyanide fishing } \\
\text { and incoming fishing boats. Each park ranger used to receive extra payments for conducting } \\
\text { night duties, but this was terminated in June 2015, further undermining enforcement capacity } \\
\text { as the lack of night patrols is widely recognised and capitalised on by poachers and illegal } \\
\text { fishers. }\end{array}$ \\
\hline
\end{tabular}

Duong T. Khuu, Peter JS. Jones and Paul Ekins (in press) A governance Analysis of Con Dao National Park, Vietnam. Marine Policy, 103986. https://doi.org/10.1016/j.marpol.2020.103986. One of 20 papers in a special section of 28 case studies on MPA Governance. 


\begin{tabular}{|c|c|c|c|}
\hline 19 & Penalties for deterrence & $\mathrm{Y}^{*}$ & $\begin{array}{l}\text { Large fines can be imposed for breaching national laws and a prison term of up to } 7 \text { years can } \\
\text { be applied for turtle poachers. Nevertheless, by June } 2016 \text {, no poachers had been penalised } \\
\text { due to a lack of political will from the district government for prosecuting violators. }\end{array}$ \\
\hline 20 & $\begin{array}{l}\text { Protection from incoming } \\
\text { users }\end{array}$ & $\mathrm{N}^{*}$ & $\begin{array}{l}\text { The operation of Ben Dam - as a hub for incoming big fishing boats to dock, trade, repair boat } \\
\text { engines and shelter during stormy days - has put more pressure on local resources. Hence, } \\
\text { enhancing the capacity for enforcement (I-18) should particularly be focused on incoming } \\
\text { fishers. }\end{array}$ \\
\hline 21 & $\begin{array}{l}\text { Attaching conditions to use } \\
\text { and property rights, } \\
\text { decentralisation, etc. }\end{array}$ & $\mathrm{N}^{*}$ & $\begin{array}{l}\text { Performance and environmental protection standards need to be attached to } \\
\text { licences/permits/ concessions given to local boats and tourism operators. Also, environmental } \\
\text { standards should be attached to decentralisation arrangements with bodies at provincial/local } \\
\text { levels in combination with more oversight from the central government to ensure such } \\
\text { environmental standards are being met. }\end{array}$ \\
\hline 22 & $\begin{array}{l}\text { Cross-jurisdictional } \\
\text { coordination }\end{array}$ & $\mathrm{Y}^{*}$ & $\begin{array}{l}\text { Although national laws expect cross-jurisdictional coordination in environmental governance } \\
\text { [51], coordination rarely exists, mostly due to the long-lasting conflict between CDNP } \\
\text { Authority and the district government. }\end{array}$ \\
\hline 23 & $\begin{array}{l}\text { Clear and consistent legal } \\
\text { definitions }\end{array}$ & $\mathrm{N}^{*}$ & $\begin{array}{l}\text { CDNP has the co-existence of forest, wetland and marine ecosystems but the legal framework } \\
\text { governing the resources of these ecosystems [52] is far from being clear and consistent } \\
\text { enough to provide for integrated management, particularly in the handling of violators. }\end{array}$ \\
\hline 25 & Legal adjudication platforms & $\mathrm{N}^{*}$ & $\begin{array}{l}\text { Conflict resolution mechanisms to support MPA governance and decision-making are needed. } \\
\text { However, due to weak state capacity and endemic governance issues, Vietnam is not ready to } \\
\text { implement this yet. }\end{array}$ \\
\hline 26 & $\begin{array}{l}\text { Transparency, accountability } \\
\text { and fairness }\end{array}$ & $\mathrm{N}^{*}$ & $\begin{array}{l}\text { A severe lack of transparency in the governance of CNDP, particularly in managing user fees, } \\
\text { enforcement and prosecution, and the availability of biodiversity and coral reef assessment } \\
\text { findings, has undermined trust and the capacity for cooperation. }\end{array}$ \\
\hline \multicolumn{4}{|c|}{ Participative } \\
\hline 27 & Rules for participation & $\mathrm{Y}^{*}$ & $\begin{array}{l}\text { Rules for community participation exist both in central and local level legislation }[53,54] \text {. } \\
\text { However, the implementation of these rules rarely happens because of inadequate financial } \\
\text { support for participation and the participation of grass-roots people in local decision-making is } \\
\text { dominated by civil society organisations with close affiliations to the Communist Party } \\
\text { (Women's Union, Farmers' Union, etc.) [27]. Thus, the legal framework should include clear } \\
\text { rules for the meaningful participation of wider local people in local decision-making. }\end{array}$ \\
\hline 28 & $\begin{array}{l}\text { Establishing collaborative } \\
\text { platforms }\end{array}$ & $\mathrm{Y}^{*}$ & $\begin{array}{l}\text { Under the UNDP/GEF project, several collaborative platforms, including the Community } \\
\text { Consultation Group (CCG), a Conservation Trust Fund and a community-based coral reef } \\
\text { monitoring group, were established [48]. However, these structures are weakly maintained as } \\
\text { the specific funding for this has ended. Furthermore, a participative MPA management plan, } \\
\text { which was legally acknowledged by CD-DPC in 2008, was rejected by BRVT-PPC due to its } \\
\text { incompatibility with Vietnam's institutional context. }\end{array}$ \\
\hline 31 & $\begin{array}{l}\text { Decentralising } \\
\text { responsibilities }\end{array}$ & $\mathrm{Y}$ & $\begin{array}{l}\text { Some management responsibilities were decentralised to BRVT-PPC. Given the current } \\
\text { weaknesses in governing CNDP and the reluctance of CD-DPC in coordination and prosecuting } \\
\text { transgressors, this needs to be reinforced by more oversight from the central government (I- } \\
\text { 21). }\end{array}$ \\
\hline 32 & Peer enforcement & $\mathrm{Y}^{*}$ & $\begin{array}{l}\text { The rules for participation have promoted the participation of Con Dao communities, including } \\
\text { divers, tourism operators, and fishers, in peer enforcement. This mechanism was financially } \\
\text { supported by the state and Conservation Trust Fund. However, the CNDP Authority's slow } \\
\text { response and lack of transparency in the handling of reports have undermined this incentive. }\end{array}$ \\
\hline 33 & $\begin{array}{l}\text { Building trust and the } \\
\text { capacity for cooperation }\end{array}$ & $\mathrm{Y}^{*}$ & $\begin{array}{l}\text { Since trust - which was built under the park's former leadership - has been eroded recently, } \\
\text { many users, especially international dive operators, have expressed disappointment in the } \\
\text { park authority due to the weak enforcement of CDNP's restrictions. By contrast, local people } \\
\text { who fish or operate tourism in CDNP, have enjoyed the state of the loosely controlled access } \\
\text { caused by the lack of leadership. }\end{array}$ \\
\hline 34 & $\begin{array}{l}\text { Building linkages between } \\
\text { relevant authorities and user } \\
\text { representatives }\end{array}$ & $\mathrm{Y}^{*}$ & $\begin{array}{l}\text { Tensions between CDNP or and CD-DPC have resulted in weak cross-jurisdictional coordination } \\
\text { (I-22) and challenged the formation of linkages between CDNP Authority and local user } \\
\text { groups. The leadership role of BRVT-PPC is instrumental in resolving the conflicts between } \\
\text { CNDP Authority and CD-DPC, and thereby, fostering positive linkages between CDNP and local } \\
\text { user groups. }\end{array}$ \\
\hline 36 & $\begin{array}{l}\text { Potential to influence higher } \\
\text { institutional levels }\end{array}$ & $\mathrm{Y}^{*}$ & $\begin{array}{l}\text { The park's former leadership had the capacity to influence the provincial government } \\
\text { regarding the park's organization, staffing and funding for conservation activities. Community } \\
\text { protest against the park's management is indicative of the potential to influence decision- } \\
\text { making at higher government levels, though such influence has actually undermined the } \\
\text { achievement of conservation objectives. At present, sustaining positive linkages between } \\
\text { CDNP and local user groups is necessary to enable CDNP's influence on the decisions taken at } \\
\text { higher government levels that could serve to strengthen several governance incentives. }\end{array}$ \\
\hline
\end{tabular}

From Table 3, it is obvious that CDNP Authority has stronger political support than other independent MPAs in Vietnam because the MPA enforcers are mandated to impose administrative sanctions to a certain extent. Regarding the funding for park management, CDNP also receives a higher amount of state funding (I-9). However, the funding is insufficient to cover a full array of management actions. Hence, ineffective enforcement 
(I-18) is identified by this analysis as the first weakness of CNDP's governance framework, especially under the increasing pressures of overfishing and tourism growth. To best address these driving forces, legal incentives, including clear and consistent legal definitions (I-23), hierarchical obligations (I-17), particularly to promote cross-jurisdictional co-ordination (I-22) and penalties for deterrence (I-19) are particularly in need of strengthening to promote more sustainable fishing and tourism (I-4). Currently, penalties for deterrence (I-19) have been undermined by the weak judicial capacity of CD-DPC that is driven by the conflicts between the district government and CDNP Authority, including patronage networks. Given the increasing decentralisation of management responsibilities to local governments (I-31) without sufficient resources and capacity and upward accountability, the supervising and oversight role of the provincial and central governments is essential to ensuring that conditions attached to decentralisation arrangements (I-21) related to environmental and governance performance standards are complied with in order to help solve such conflicts. Furthermore, measures to protect from the incoming users (I-20), particularly fishers, requires cross-jurisdictional coordination $(\mathrm{I}-22)$ at a trans-provincial level, thus requiring higher-level legal and political interventions from the central state. Other legal instruments, including transparency, accountability and fairness (I-26) along with legal adjudication platforms (I-25) to promote this are also needed to improve the governance of CDNP. However, due to the low state capacity and patronage network issues, the state is arguably not yet ready to implement such incentives.

Overall, the weaknesses of legal incentives in this analysis first imply a lack of political will from the central government in building a robust and comprehensive legal framework, and also in implementing the existing laws effectively and equitably. In such circumstances, top-down hierarchical obligations related to the CBD and RAMSAR (I-17) can help promote political will from the central Vietnamese government in improving its conservation measures. However, evaluating the success and failure in implementing such conventions significantly depends on the quality of the reports prepared by MONRE, though their role in steering Vietnam's environmental protection strategies is controversial [2]. The second weakness is a lack of genuine participation from local communities and users, which has ironically resulted from the promotion of green marketing (I-5) and measures to reduce the leakage of benefits (I-3) without strict environmental standards attached (I-21), perversely incentivising a focus on the maximization of personal income opportunities rather than seeking to participate in decisions and their implementation. Subsequently, peer enforcement (I-32) has not effectively complemented the park's weak capacity for enforcement (I-18), partly due to the lack of transparency, accountability and fairness (I-26), noting that many of the local users engaging in peer enforcement are also reported as being among those who violate the MPA regulations.

CDNPs restrictions are widely recognised but tend to be neglected, not least of all because the rangers are allegedly among the violators. These issues have undermined trust and capacity for cooperation (I-33), particularly among dive operators. The third weakness is a lack of awareness of the MPA's conservation features (I-11), of the benefits of protection (I-12) and of related regulations (I-13) across all government levels and sectors and among different user groups. Although NGOs have supported CDNP in implementing various interpretative incentives, the campaigns have been short-term, unlinked with one another, and some have even disrupted the existing structures, e.g. the fishers, who were beneficiaries of alternative livelihood programmes, have often been violators of NTZ regulations, due to the privilege of operating tourism within CDNP and lack of awareness of park rangers. Therefore, it is essential to strengthen interpretative incentives through welldesigned and consistent awareness and education programmes in a way which is in alignment with the fulfilment of strategic conservation objectives. The potential benefits of the MPA also need to be perceived as long-term rather than short-term, particularly tourism. Awareness needs to be raised at all levels, from tourists needing to recognise MPA regulations and restrictions through to raising awareness among higher-level officials. The leadership roles of the park management and NGOs are essential for awareness-raising and policy advocacy.

Whilst addressing the wider problems of endemic corruption among state and private actors in Vietnam could take decades, promoting a better understanding of the need for sustainable development, ecotourism and smarter long-term investments could help to this end. Among community members, a lack of awareness is partly driven by the unfair distribution of MPA benefits, particularly given that poor fishers were marginalised from alternative livelihood initiatives (I-6). Therefore, they have continued fishing in the MPA and the rangers felt sympathy for these fishers because the rangers have also been treated unfairly due to poor pay and work conditions. Given these and related challenges, Payments for Ecosytem Services (PESs), e.g. Blue Carbon

Duong T. Khuu, Peter JS. Jones and Paul Ekins (in press) A governance Analysis of Con Dao National Park, Vietnam. Marine Policy, 103986. https://doi.org/10.1016/j.marpol.2020.103986. One of 20 papers in a special section of 28 case studies on MPA Governance. 
schemes, and other incentives that promote the flows of economic benefits from the receivers of ecosystem services (tourists, tourism operators and developers) to those who help support the provision of these services (forest rangers, fisheries regulators, sustainable small-scale fishers, etc.) are worth considering, e.g. reducing the leakage of benefits (I-3). However, the weak regulatory framework, under the tight control of the Communist Party, which tends to favour large-scale developments, could arguably undermine such direct flows of economic benefits, providing little political support for small-scale sustainable developments. This argument resonates with empirical findings from a case study of implementing PES initiatives in Vietnam, which particularly raised concerns over the potential of PESs to reduce poverty because PES initiatives are mainly driven by the government's interest in using them to generate additional funding to sustain state management structures rather than benefiting local resource users [55].

\section{Cross-cutting issues}

\subsection{Role of leadership}

The role of CNDP's former director was instrumental to the success of most of the incentives, particularly the provision of MPA funding from the state (I-9) and NGOs (I-10), capacity for enforcement (I-18), building trust and the capacity for cooperation (I-34), building linkages between authorities and users (I-34), and the potential to influence higher institutional levels (I-36). After thirty years of working at CDNP, the director was trusted by the ranger force, local communities and the international diving community because of his understanding and willingness to listen to and respond to their needs. However, due to unsolvable conflicts between the park director and Con Dao district government, along with changes in the province's leadership, the director was replaced in June 2015, leading to many of the current weaknesses in the governance structure of CDNP. Meanwhile, due to a lack of awareness of and interest in environmental protection, the political will of the country's leaders is still more focused on development priorities, resulting in an ambiguous legal framework that has ignored the need to define development thresholds within protected areas. Consequently, incomplete decentralisation without sufficient conditions and oversight (I-21) has encouraged rent-seeking behaviour among local economic and political elites, thereby leading to more development in CDNP. This pattern is prevalent in most protected areas in Vietnam, including in CDNP, a previously isolated archipelago. Under such development pressures, the lack of political will from the central state to promote conservation and address related rent seeking issues has been among the main reasons for the fragility and ineffectiveness of CDNP's governance framework.

\subsection{Social Equity}

Under the UNDP/GEF project, decisions on alternative income generation (AIG) options (I-6) and beneficiaries were made through socio-economic surveys and consultations with CDNP Authority, Community Consultation Group, CD-DPC, the border guard, tourism operators/developers, and local fishers. However, the implementation of such programmes was unsuccessful due to unrealistic designs. Aquaculture models failed after a three-month trial due to parasites. In operating ecotourism, 17 people from the target group and 20 Con Dao residents benefited from the training in boat operation and basic communication skills. However, only a few of them have successfully engaged in tourism-related jobs and enjoyed the benefits of this new livelihood. Like other MPAs in Vietnam, there is elite capture of benefits because only a few favoured representatives from residential areas participated in consultation workshops and meetings, with no comprehensive socio-economic assessments undertaken before the selection of these representatives. Consequently, given that linkages between rangers and the AIG beneficiaries were built up during the implementation of collective learning, alternative livelihoods, and peer enforcement initiatives, forest rangers do not apply their enforcement capacity on the locals that conduct irresponsible tourism activities, which has undermined the achievement of CDNP's conservation objectives and caused resentment in the professional diver community. Therefore, it is vital to promote wider community participation in park planning and management and build trust between user groups, communities, local authorities, and CDNP Authority in monitoring and enforcement. Participation and economic benefits must reach wider constituencies. Given the increasing influx of migrants, there is likely to be more citizens with no sense of island stewardship, i.e. the mainlandisation issue [42], therefore raising awareness must remain a focus as an essential part of the park management plan to ensure effective and equitable development opportunities.

Duong T. Khuu, Peter JS. Jones and Paul Ekins (in press) A governance Analysis of Con Dao National Park, Vietnam. Marine Policy, 103986. https://doi.org/10.1016/j.marpol.2020.103986. One of 20 papers in a special section of 28 case studies on MPA Governance. 


\subsection{Role of NGOS}

In CDNP, NGOs mostly acted as a funder of small/medium grant projects or an implementer of donor-funded projects that focused on the protection of endangered species using the economic, interpretative and participative incentives discussed. Overall, these short-term projects did not contribute significantly to achieving strategic conservation objectives. Besides, operating in a centralised state has limited NGOs' scope to advance civil society because decision-making at the grassroots level often stop at a commune level (or at a district level in Con Dao) with a significant involvement of mass organisations (e.g. Women's Union, Farmers' Union, Youth Organisation, etc.) through which the Communist Party supervises its people. Considering these shortcomings, NGOs could be more critical in governing CNDP. For example, they might focus their resources and expertise on undertaking comprehensive assessments on environmental impacts of economic development, or on socioeconomic assessments that account for the aspiration of wider Con Dao communities. Based on the assessment results, NGOs could advocate for behavioural change at the central level, or for more influence from the international community to stimulate political will from the Vietnamese government for environmental protection.

\section{Conclusion}

Overall, the governance of CNDP is characterised by a lack of steer and intervention from the central government and decentralisation to the provincial government with very few conditions attached and the very limited participation of local communities. The park management capacity and interventions of international donors and NGOs have been mostly focused on addressing localised environmental impacts of illegal fishing and turtle hunting. However, such efforts, while having failed to limit the intensity of turtle poaching and cyanide fishing, have resulted in some harmful linkages undermining conservation, and have led to the diversion of attention towards pursuing legal incentives to promote the tokenistic and ineffective coordination and participation platforms. In such circumstances, the lack of political will and strategic planning has resulted in the forthcoming expansion of tourism infrastructure and offshore fishing, which is much more of a critical concern than the localised impacts that are 'beginning to be addressed'. Behind all the governance problems lies a lack of awareness and communication among government officials, tourism operators and developers, tourists, and local communities, which is being driven by the utilitarian views and short-term visions towards resource use to generate income and lack of focus on conservation.

The current weaknesses in governing CNDP critically reflect the recurring issues in governing MPAs in Vietnam, i.e., weaknesses in both the steering role of the state and the participation of local communities and overreliance on international aid, leading to institutional capture by vested interests between local governments and the private sector. These setbacks have rendered most incentives ineffective and short-lived in the context of strong economic development forces. Among three studied MPAs in Vietnam in this special section, CDNP reveals the highest degree of state intervention in governing MPAs, though the problems of the ambiguous legal framework and lacking capacity for enforcement are still major, especially in the context of intensifying impact from corporate tourism. Thus, this study supports arguments that the leading role of the state is essential to ensure that MPA initiatives are working towards effectively and equitably achieving their conservation objectives. It thereby reconfirms the feasibility of the MPAG framework being a realist institutional analysis framework for protected area governance studies.

\section{Declaration of competing interest: None.}

\section{Acknowledgements}

The authors would like to thank IUCN Vietnam for providing an internship that has contributed enormously to the data collection for this research. The authors are also grateful to Con Dao National Park Management Authority and Con Dao district government - who strongly supported our field trip in Con Dao islands between May and July 2016. This PhD was supported by UCL Institute for Sustainable Resources and BHP Billiton Scholarship.

Duong T. Khuu, Peter JS. Jones and Paul Ekins (in press) A governance Analysis of Con Dao National Park, Vietnam. Marine Policy, 103986. https://doi.org/10.1016/j.marpol.2020.103986. One of 20 papers in a special section of 28 case studies on MPA Governance. 


\section{References}

[1] Jones, P.J.S., 2014. Governing Marine Protected Areas: Resilience through Diversity. Oxon, UK: Routledge.

[2] Khuu, T.D., 2018. Reconciling biodiversity conservation with sustainable development: a case study of Marine Protected Area (MPA) governance in Vietnam. PhD thesis. London,UK: University College London.

[3] To be added

[4] WWF, 1993. Survey Report on the Biodiversity Resourse Utilization and Conservation Potential of Hon Mun, Cat Ba Region, Haiphong, Vietnam. Gland, Switzerland: WWF Vietnam Marine Conservation Southern Survey Team.

[5] Government of Vietnam, 2010. Decision 742/QD-TTg adopted by the Prime Minister on 'approving the masterplan for the establishment of MPA system towards 2020' on 26 May 2010.

[6] WWF, 2001. Assessment of legal documents and policies relating to management of special-use forest in Vietnam. Hanoi: WWF.

[7] GOV \& GEF, 1994. The Biodiversity Action Plan for Vietnam. Hanoi, Vietnam: (n.p.).

[8] World Bank, 1995. 'Central Indian Ocean, Arabian Seas, East Africa and East Asia Seas', World Bank (ed.) A Global Representative System of Marine Protected Areas. Washington D.C. Available at: http://documents.worldbank.org/curated/en/734481468779992440/pdf/multiOpage.pdf (Accessed: 12 September 2017).

[9] Ba Ria-Vung Tau Provincial People's Committee, 1998. Decision 1165/QD-UB on 'approving the development masterplan for CDNP during 1998-2002' on 16 May 1998.

[10] UNDP, 2001. PDA Funding for Full Project - Biodiversity Conservation and Sustainable Use of the Marine Resources at Con Dao National Park. New York: UNDP.

[11] Le, X.A. \& Tran, D.H., 2013. 'Conservation of Biodiversity Resources for Sustainable Development of Con Dao', National Conference of Ecology and Biological Resources, Hanoi, Vietnam. (in Vietnamese).

[12] CDNP Authority, 2016. Ecotourism Development Project for Con Dao National Park period 2016-2020. Con Dao, Vietnam: CDNP Authority. (in Vietnamese).

[13] RAMSAR, 2016. Available at: http://www.ramsar.org/wetland/vietnam? site=32211\#map-leaflet (Accessed: 08 February 2016).

[14] Vo, S.T., 2000. The corals at Con Dao Archipelago (South Vietnam): Before, During and After the Bleaching Event in 1998. Bali, Indonesia: (n.p.).

[15] CDNP Authority, 2014. Achievements from Forest Protection and Biodiversity Activities 2014 and tasks for 2015. Con Dao, Vietnam: CDNP Authority. (in Vietnamese).

[16] Nguyen, T.G., 2003. Biodiversity Conservation in Con Dao: Status and Ecological Characteristics of Green Turtles (Chelonia Mydas) and Conservation Solutions at Con Dao National Park. Con Dao, Vietnam: CDNP Authority, Science Division.

[17] Johns, A.G., O'Callaghan, B., Primmer, R., Thanh, N.C. \& Ho, V.T.T., 2008. The Management Plan for Con Dao National Park. Con Dao, Vietnam: Con Dao National Park.

[18] Mittermeier, R.A., Gil, P.R., Hoffman, M., Pilgrim, J., Brooks, T., Mittermeier, C.G., Lamoreux, J. \& DaFonseca, G.A.B., 2004. Hotspots Revisited: Earth's Biologically Richest and Most Endangered Terrestrial Ecoregions. Mexico city: CEMEX.

[19] Spalding, M.D., Fox, H.E., Allen, G.R., Davidson, N., Ferdana, Z.A., Finlayson, M., Halpern, B. \& Jorge, M.A., 2007. Marine Ecoregions of the World: A Bioregionalization of Coastal and Shelf Areas. BioScience, 57(7), pp. 573-583. DOI: https://doi.org/10.1641/B570707.

[20] United Nations, 2018. World Economic Situation and Prospects 2018. New York: United Nations. 
[21] WWF, 2012. Wildlife Crime Scorecard-Assessing compliance with and enforcement of CITES commitments for tigers, rhinos and elephants. Gland, Switzerland: WWF. Available at:

http://awsassets.panda.org/downloads/wwf_wildlife_crime scorecard report.pdf (Accessed: 21 June 2017).

[22] Jambeck, J.R., Geyer, R., Wilcox, C., Siegler, T.R., Perryman, M., Andrady, A., Narayan, R. \& Law, K.L., 2015. Plastic waste inputs from land into the ocean. Science, 347 (6223), pp.768-771. DOI:

https://doi.org/10.1126/science.1260352.

[23] Kreft, S., Eckstein, D. \& Melchior, I., 2016. Global Climate Risk Index 2017. Who suffersmost from extreme weather events? weather-related loss events in 2015 and 1996-2015. Berlin: Germanwatch e.V. Available at:

https://www.elsevier.com/wps/find/journaldescription.cws home/30453?generatepdf=true (Accessed: 21 June 2017).

[24] Zingerli, C., 2005. Colliding Understandings of Biodiversity Conservation in Vietnam: Global Claims, National Interests, and Local Struggles. Society \& Natural Resources, 18(8), pp. 733-747. DOI: https://doi.org/10.1080/08941920591005151 .

[25] Gainsborough, M., 2002. Political Change in Vietnam: In Search of the Middle-Class Challenge to the State. Asian Survey, 42(5), pp. 694-707. DOI: https://www.jstor.org/stable/10.1525/as.2002.42.5.694?seq=1 .

[26] Qiu, W. (2013) 'The Sanya Coral Reef National Marine Nature Reserve, China: A governance analysis', Marine Policy, 41, pp. 50-56. DOI: https://doi.org/10.1016/i.marpol.2012.12.030 .

[27] Brown, P. (2013) Marine Protected Areas, Co-management and Livelihoods: Coastal Change in Vietnam. PhD Thesis. University of Sydney.

[28] World Bank, 2017. The World Bank-databank. Available at:

http://data.worldbank.org/indicator/ST.INT.ARVL?locations=VN (Accessed: 21 June 2017).

[29] GSO, 2016. Statistical Yearbook of Vietnam 2016, Hanoi: General Statistics Office of Vietnam.

[30] World Bank, 2016. Worldwide Governance Indicators. Available at: www.govindicators.org [Accessed: 17 December 2017].

[31] UNDP, 2016. Human Development Report 2016: Human Development for Everyone. New York, US: UNDP. Available at: http://hdr.undp.org/sites/default/files/2016 human development report.pdf (Accessed: 21 June 2017).

[32] Nguyen, D.T., 2012. Con Dao from an Historical Perspective. Ho Chi Minh City, Vietnam: Ho Chi Minh Publishing House. (in Vietnamese).

[33] Hayward, P. \& Nguyen, T.H.G., 2014. At the Edge: Heritage and Tourism development in Vietnam's Con Dao Archipelago. Journal of Marine and Island Culture, 3, pp. 113-124. DOI:

https://doi.org/10.1016/i.imic.2014.10.002.

[34] Government of Vietnam, 2005. Decision 264/2005/QD-TTg adopted by the Prime Minister on 'approving the socio-economic development master plan for Con Dao district, Ba Ria-Vung Tau Province towards 2020' on 25 October 2005.

[35] CD-DPC, 2015. Socio-Economic development report for 2014 and development tasks for 2015. Con Dao, Vietnam: Con Dao District People's Committee. (in Vietnamese).

[36] Government of Vietnam, 2009. Decision 120/QD-TTg adopted by the Prime Minister on 'approving the Development Masterplan for Con Dao National Park, Ba Ria-Vung Tau Province towards 2020' on 21 January 2009.

[37] FIPI, 2009. A Development Masterplan for Con Dao National Park towards 2020. Ho Chi Minh City, Vietnam: Sub-Department of Forestry and Planning for Southern Vietnam.

[38] Government of Vietnam, 2015. Decision 870/QD-TTg adopted by the Prime Minister on 'approving the ecotourism development master plan for Con Dao-national tourism area towards 2030' on 17 June 2015.

[39] Government of Vietnam, 2013. Decision 32/2013/QD-TTg adopted by the Prime Minister on 'the mechanisms and incentive policies for Con Dao district, Ba Ria-Vung Tau province' on 22 May 2013. 
[40] Commerce Vietnam, 2011. Ben Dam port of Con Dao. Available at: http://www.thuongmai.vn/danhba/cang-bien/danh-sach-cang-bien/915-cang-bien-condao-cac-dao-tay-nam/70602-cang-ben-dam-con-daovung-tau.html (Accessed: 08 March 2017). (in Vietnamese).

[41] Tze-Ken, D.W. (2012) 'The Destruction of the English East India Company Factory on Condore Island', Modern Asian Studies, 46 (5), pp. 1097-1115. DOI: https://doi.org/10.1017/S0026749X11000424.

[42] Jones, P.J.S. (2013) 'A governance analysis of the Galápagos Marine Reserve', Marine Policy, 41, pp. 6571. DOI: https://doi.org/10.1016/i.marpol.2012.12.019.

[43] CDNP Authority (2015a) Biodiversity Monitoring Report 2015. Con Dao, Vietnam: CDNP Authority, Marine and Wetland Conservation Division. (in Vietnamese).

[44] Government of Vietnam, 1991. Law No. 58-LCT/HDND8 adopted by the National Assembly on 'Forest Protection and Development' on 12 August 1991.

[45] Government of Vietnam, 2010. Decree 117/2010/ND-CP adopted by the Government on 'the management of SUF system' on 24 December 2010.

[46] Chu, T.C., 2013. Climate Change impacts on the Marine Turtles in Vietnam. Vietnam: Vietnam Academy of Science and Technology. (in Vietnamese).

[47] Chou, L.M., Vo, S.T, Philreefs, Yeemin, T., Cabanban, A., Suharsono, 2002. Status of Southeast Asia Coral Reefs, in C. Wilkinson (ed.) Status of Coral Reefs of the World: 2002. Townsville, Queensland: Australian Institute of Marine Science, pp. 123-152. Available at:

https://www.icriforum.org/sites/default/files/GCRMN 2002.pdf (Accessed: 21 June 2017).

[48] Vandemeeren, S. \& Phan, N.H.T., 2009. Final Evaluation of the UNDP-GEF Project: Coastal and Marine Biodiversity Conservation and Sustainable Use in the Con Dao islands.

[49] Hughes, T.P., 1994. Catastrophes, Phase Shifts, and Large-Scale Degradation of a Caribbean Coral Reef. Science, 265 (5178), pp. 1547-1551. DOI: https://doi.org/10.1126/science.265.5178.1547.

[50] Boaden, A. \& Kingsford, M., 2015. Predators drive community structure in coral reef fish assemblages. Ecosphere, 6 (4), pp. 1-33. DOI: https://doi.org/10.1890/ES14-00292.1.

[51] Government of Vietnam, 2002. Circular 144/2002/TTLT/BNNPTNT-BCA-BQP - a joint circular adopted by Ministry of Agriculture and Rural Development, Ministry of Public Security, and Ministry of National Defence on 'guiding the coordination among forest rangers, public police, and border guard'.

[52] Ba Ria-Vung Tau Provincial People's Committee, 2016. Decision 1185/QD-UBND adopted by Ba Ria-Vung Tau Provincial People's Committee on 'approving the management strategy for the protection and wise use of CNDP RAMSAR site' on 13 May 2016.

[53] Government of Vietnam, 2014. Circular 105/2014/TT-BTC adopted by Ministry of Finance on 'the procedures for collection and payment of fine, fine payment receipts and funds from the state budget to ensure the operation of forces sanctioning administrative violations' on 07 August 2014.

[54] CDNP Authority, 2009. Marine Resources of Con Dao National Park. Con Dao, Vietnam: Hong Duc Publishing House. (in Vietnamese).

[55] Suhardiman, D., Wichelns, D., Lestrelin, G. \& Chu, H.T., 2013. Payments for ecosystem services in Vietnam: Market-based incentives or state control of resources? Ecosystem Services, 5, pp. 94-101. DOI:

https://doi.org/10.1016/i.ecoser.2013.06.001. 


\title{
Appendix A. Supplementary materials
}

\author{
Incentives used in the governance of CNDP
}

\begin{tabular}{|c|c|c|c|}
\hline No. & Incentive & Used & How/Why \\
\hline \multicolumn{4}{|c|}{ Economic } \\
\hline 1 & $\begin{array}{l}\text { Payment for } \\
\text { Ecosystem Services } \\
\text { (PESs) }\end{array}$ & $\mathrm{N}^{*}$ & $\begin{array}{l}\text { Because of the unjust sharing of costs and benefits, PESs (e.g. Blue carbon) is worth considering. } \\
\text { Nonetheless, Vietnam's immature regulatory framework could make this incentive ineffective at a } \\
\text { CDNP operational level due to the risk of rent seeking and fund appropriation at higher levels. }\end{array}$ \\
\hline 3 & $\begin{array}{l}\text { Reducing the leakage } \\
\text { of benefits }\end{array}$ & $\mathrm{Y}^{*}$ & $\begin{array}{l}\text { diving and snorkelling) being waived for tourists. Each park ranger was given US\$1 as a reward for } \\
\text { a night shift of protecting turtles and their nests. Since June 2015, rangers have not been rewarded } \\
\text { due to the suspension of user fee collection and local boats have not respected the park's } \\
\text { regulations. }\end{array}$ \\
\hline 4 & $\begin{array}{l}\text { Promoting profitable } \\
\text { and sustainable fishing } \\
\text { and tourism }\end{array}$ & $\mathrm{Y}^{*}$ & $\begin{array}{l}\text { The MPA component of CDNP is a multiple-use MPA with NTZs occuping } 12.4 \% \text { of the total MPA } \\
\text { area and banning all extractive activities while allowing some ecotourism activities. However, as } \\
\text { most tourism operators do not follow the park's regulations, anchoring on the protected reefs } \\
\text { plays out daily, thus undermining the stock recovery and spill-over/export benefits of the NTZs for } \\
\text { surrounding fisheries. The situation is tolerated by CDNP Authority because the park has } \\
\text { insufficient capacity for controlling the impacts of tourism. }\end{array}$ \\
\hline 5 & $\begin{array}{l}\text { Promoting green } \\
\text { marketing }\end{array}$ & $\mathrm{Y}^{*}$ & $\begin{array}{l}\text { A cap of } 24 \text { tourists has been adopted for sea turtle observation in Bay Canh island. This strict limit } \\
\text { is employed to market CDNP's turtle observation tours as 'eco' making them a flagship for } \\
\text { ecotourism in CDNP. This marketing strategy resulted in the price premium (US\$40/person/tour) } \\
\text { and contributed to increasing income for CDNP - of which } 10 \% \text { was used as financial support for } \\
\text { rangers. However, since CDNP is currently not allowed to provide such tours, this incentive is } \\
\text { undermined by the limited awareness of tourism operators and insufficient capacity for } \\
\text { enforcement. Thus, the cap is often exceeded and tourists' bad behaviour (e.g. taking photos with } \\
\text { the flashlight on or hopping on the adult turtles,) are tolerated by the rangers. The recent Ramsar } \\
\text { designation has been used to promote ecotourism throughout Con Dao, but with a focus on the } \\
\text { 'international title' rather than on the hierarchical obligations under such designation. }\end{array}$ \\
\hline 6 & $\begin{array}{l}\text { Promoting diversified } \\
\text { and supplementary } \\
\text { livelihoods }\end{array}$ & $\mathrm{Y}^{*}$ & $\begin{array}{l}\text { The UNDP/GEF project attempted several Alternative Income Generation (AIG) activities (seaweed } \\
\text { farming, upgrading fishing boats to tourist boats, etc.) most of which, however, are no longer } \\
\text { viable due to unrealistic designs. Local fishers, who benefited from the boat upgrading initiative, } \\
\text { often ignore the park's regulations (anchoring on reef, littering, fishing in the NTZs, etc.). The } \\
\text { project also established and invested US\$50,000 in the Conservation Trust Fund to project to build } \\
\text { community capacity in ecotourism operation and engage tourism operators/developers in the } \\
\text { management of CDNP. However, since the project ended in } 2009 \text {, this fund is weakly sustained by } \\
\text { tourists' random cash donation ( US\$450 per year). }\end{array}$ \\
\hline 9 & $\begin{array}{l}\text { Provision of state } \\
\text { funding }\end{array}$ & $\mathrm{Y}^{*}$ & $\begin{array}{l}\text { Due to the 'National Park' title, CDNP is principally financed by state funding. Annual state budget } \\
\text { ( US\$500,000) is directly allocated to staff salaries, infrastructure and utility costs. Also, state } \\
\text { budget channelled through the provincial government funds the park's daily activities (patrolling: } \\
\text { US\$60,000/year, scientific research and monitoring: US\$100,000/year). Other sources include } \\
\text { funding from donors that was channelled through the state budget in ODA form and invested in } \\
\text { purchasing two patrol boats but funding the running and maintenance of these is a challenge. } \\
\text { More funding is needed for more sea patrols and regular monitoring. }\end{array}$ \\
\hline 10 & $\begin{array}{l}\text { Provision of NGO, } \\
\text { private sector and } \\
\text { user fee funding }\end{array}$ & $\mathrm{Y}^{*}$ & $\begin{array}{l}\text { Since 1995, NGO funding received by CDNP was mostly invested in scientific research and } \\
\text { monitoring of sea turtles, purchasing of equipment (turtle tags, torch lights, etc.), and raising } \\
\text { public awareness. After all sources NGO funding finished in } 2012, \text { such activities have been } \\
\text { continued by the income (about) generated from ecotourism ( US\$200,000/year, including } \\
\text { entrance and user fees, renting boats, lodging tourists at ranger stations and providing sea turtle } \\
\text { observation tours, etc.) that has been disrupted recently, leading to the shortage of funding to } \\
\text { continue such activities. Besides, without rewards, many rangers have lost their motivation for the } \\
\text { job and developed partnerships with poachers. So far, the park has not received any funding from } \\
\text { tourism operators/developers, despite a significant proportion of conservation benefits having } \\
\text { been accrued to this user group. }\end{array}$ \\
\hline \multicolumn{4}{|c|}{ Interpretative } \\
\hline 11 & Raising awareness & $\mathrm{Y}^{*}$ & $\begin{array}{l}\text { Before essential information on CDNP's endangered and protected species was communicated } \\
\text { using booklets and brochures. Awareness-raising sessions were held in residential areas, on fishing } \\
\text { boats, and in the Army. Recently, due to the halt of user fee collection, these activities are irregular } \\
\text { and dependent on staff capacity in gaining NGO funding. Despite some NGO small-grant projects } \\
\text { focusing on environmental education for school children and raising awareness in the wider public, } \\
\text { these projects are short-term and non-systematic in nature. Therefore, more engaging materials } \\
\text { and methods should be employed to ensure effectiveness and consistency. }\end{array}$ \\
\hline 12 & $\begin{array}{l}\text { Promoting recognition } \\
\text { of benefits }\end{array}$ & Y & $\begin{array}{l}\text { Potential benefits (through spillover/exports, tourism, etc.) of protecting the target resources were } \\
\text { promoted through awareness raising sessions. The community awareness of protecting coral reefs } \\
\text { was also promoted through capacity building programmes (training in Reef-check, coral reef } \\
\text { rehabilitation, etc.). Besides, the recognition of the benefits of keeping Con Dao free from plastics } \\
\text { was encouraged occasionally through several garbage collection events with the voluntary }\end{array}$ \\
\hline
\end{tabular}




\begin{tabular}{|c|c|c|c|}
\hline & & & $\begin{array}{l}\text { participation of local communities and authorities. However, this incentive is undermined by } \\
\text { ineffective enforcement, weak coordination, and a lack of community stewardship for protecting } \\
\text { local resources. Since no conservation benefit is currently noticeable, it might be more realistic to } \\
\text { focus capacity on enhancing 'promoting sustainable and profitable fishing and tourism' incentive. }\end{array}$ \\
\hline 13 & $\begin{array}{l}\text { Promoting recognition } \\
\text { of regulations and } \\
\text { restrictions }\end{array}$ & $\mathrm{Y}^{*}$ & $\begin{array}{l}\text { Signboards were erected in some residential areas and ranger stations to inform the public about } \\
\text { zoning regulations and restrictions. Banners, posters, and signboards were also used to } \\
\text { communicate the illegality and penalisation of hunting and trading sea turtles. Nonetheless, owing } \\
\text { to the lack of capacity and transparency and fairness in enforcement and handling of violations } \\
\text { combined with the short-sightedness of some user groups (AIG beneficiaries, tourism } \\
\text { operators/developers), CNDP regulations and restrictions are regularly ignored in reality, despite } \\
\text { being well recognised. Thus, this needs to be strengthened by regularly communicating regulations } \\
\text { to tourists. It can also be reinforced by strengthening the capacity in enforcement and penalising } \\
\text { MPA violators. }\end{array}$ \\
\hline \multicolumn{4}{|c|}{ Knowledge } \\
\hline 14 & $\begin{array}{l}\text { Promoting collective } \\
\text { learning }\end{array}$ & $\mathrm{Y}^{*}$ & $\begin{array}{l}\text { As most CNDP's staff was specialised in forest protection, working alongside marine ecologists in } \\
\text { donor-funded biodiversity assessments has enhanced the capacity of park rangers in marine } \\
\text { conservation and management. The UNDP/GEF project also helped to connect local fishers with } \\
\text { scientists and build capacity for local fishers in scuba diving and coral rehabilitation. CDNP has } \\
\text { sometimes been advised by an international diving operator (regarding the conservation of sea } \\
\text { turtles and giant clams). Currently, due to a shortage of funding for regular coral reef monitoring, it } \\
\text { could be cost-effective to promote collaboration with the international dive operators and local } \\
\text { diving fishers. }\end{array}$ \\
\hline \multicolumn{4}{|c|}{ Legal } \\
\hline 17 & $\begin{array}{l}\text { Hierarchical } \\
\text { obligations }\end{array}$ & $\mathrm{Y}^{*}$ & $\begin{array}{l}\text { International legal obligations supporting the achievement of CDNP's conservation objectives are } \\
\text { those under the CBD, CITES, and RAMSAR conventions. National laws supporting the enforcement } \\
\text { of park regulations include the Fisheries Law of 2003, the Forest Protection and Development Law } \\
\text { of } 2004 \text {, the Environmental Protection Law of } 2005 \text {, and the Biodiversity Law of } 2008 \text {. Sea turtles } \\
\text { are protected by Article } 190 \text { of the Criminal Code of } 2009 \text {. However, under this unclear framework } \\
\text { - with both overlaps and conflicts between responsible agencies - CDNP Authority, with capacity } \\
\text { being focused on forest protection, must on other forces for the handling of serious violations and } \\
\text { prosecutions in enforcing MPA regulations, and the conflicts between CDNP Authority and CD-DPC } \\
\text { hamper the coordination. Therefore, it is essential to revise and reform the current legal } \\
\text { framework considering the essence of legal provisions for 'cross-jurisdictional coordination' among } \\
\text { authorities and conflict resolution platforms, and 'clear and consistent legal definitions'. }\end{array}$ \\
\hline 18 & $\begin{array}{l}\text { Capacity for } \\
\text { enforcement }\end{array}$ & $\mathrm{Y}^{*}$ & $\begin{array}{l}\text { Compared to other MPAs in Vietnam's MPA network, CDNP has higher capacity for enforcement } \\
\text { because of the 'National Park' designation and higher advocacy capacity of the park's former } \\
\text { leadership. } 70 \text { forest rangers are assigned to } 11 \text { ranger stations across CDNP's islands to oversee } \\
\text { turtle nesting beaches, protected forests, and coral reef areas, and a mobile ranger team accounts } \\
\text { for } 70 \% \text { of the Park's surveillance activities. Each of eight ranger stations is equipped with a 15- } \\
\text { horsepower patrolling boat (provided by BRVT-PPC). The mobile ranger team has a 60-horsepower } \\
\text { speedboat. Rangers are empowered to impose certain kinds of administrative sanctions on MPA } \\
\text { violators. However, due to the scattering of turtle nesting beaches, enforcement capacity is still } \\
\text { insufficient, especially in protecting the NTZs from cyanide fishing and incoming fishing boats. } \\
\text { Coordination between CDNP rangers, fisheries inspectors and the border guard should be } \\
\text { improved. }\end{array}$ \\
\hline 19 & $\begin{array}{l}\text { Penalties for } \\
\text { deterrence }\end{array}$ & $\mathrm{Y}^{*}$ & $\begin{array}{l}\text { Large fines can be imposed for breaching national laws and a prison term (up to } 7 \text { years) can be } \\
\text { sentenced for turtle poachers. Nevertheless, by June 2016, no poachers had been penalised. Also, } \\
\text { with judicial capacity being concentrated within the district government, a lack of local political } \\
\text { support has made this incentive insufficient to deter others. }\end{array}$ \\
\hline 20 & $\begin{array}{l}\text { Protection from } \\
\text { incoming users }\end{array}$ & $\mathrm{N}^{*}$ & $\begin{array}{l}\text { The operation of Ben Dam port since } 2000-\text { as a hub for incoming big fishing boats to dock, trade, } \\
\text { repair boat engines and shelter during stormy days - has put more pressure on local resources. } \\
\text { Hence, enhancing 'the capacity for enforcement' should particularly be focused on incoming } \\
\text { fishers. Increasing coordination with CD-DPC is essential to encourage the port authority to } \\
\text { recognise the MPA regulations and integrate such regulations into its management. }\end{array}$ \\
\hline 21 & $\begin{array}{l}\text { Attaching conditions } \\
\text { to use and property } \\
\text { rights, } \\
\text { decentralisation, etc. }\end{array}$ & $\mathrm{N}^{*}$ & $\begin{array}{l}\text { Performance and environmental protection standards need to be attached to licences or permits or } \\
\text { concessions given to local boat and tourism operators. Also, environmental standards as obligations } \\
\text { attached should be attached to decentralisation in combination with more oversight from the } \\
\text { central government to ensure such environmental standards are being met). }\end{array}$ \\
\hline 22 & $\begin{array}{l}\text { Cross-jurisdictional } \\
\text { coordination }\end{array}$ & $\mathrm{Y}^{*}$ & $\begin{array}{l}\text { Although national laws signify 'cross-jurisdictional coordination' in environmental governance, } \\
\text { coordination rarely exists in reality. In enforcing the park regulations, CDNP follows a joint circular } \\
\text { - a legal basis for participative mechanisms between the park authority, police and border guard in } \\
\text { forest protection [51]. However, in the MPA, Although the Ramsar designation resulted in a } \\
\text { provincial decision in } 2016 \text { on establishing coordinating mechanisms between CDNP Authority, } \\
\text { fisheries inspectors, border guard and local communities in promoting the conservation and wise } \\
\text { uses of marine and wetland resources [52], coordination does not exist. The management board of } \\
\text { the Conservation Trust Fund (formed by the UNDP/GEF project) comprises representatives from } \\
\text { CDNP Authority, CD-DPC and mass organisations to promote cross-jurisdictional coordination. }\end{array}$ \\
\hline 23 & $\begin{array}{l}\text { Clear and consistent } \\
\text { legal definitions }\end{array}$ & $\mathrm{N}^{*}$ & $\begin{array}{l}\text { CDNP has a co-existence of forest, wetland, and marine ecosystems. Thus, the legal framework } \\
\text { governing these resources is far from being clear and consistent to provide for the integrated } \\
\text { management, notably in the handling of violators. For instance, since turtles became under the }\end{array}$ \\
\hline
\end{tabular}




\begin{tabular}{|c|c|c|c|}
\hline & & & $\begin{array}{l}\text { auspices of the Criminal Code, CDNP must rely more on CD-DPC for penalising violations; and given } \\
\text { the vague legal framework and on-going conflicts between CDNP Authority and CD-DPC, } \\
\text { penalisation has been more challenging due to the unwillingness of CD-DPC to cooperate. }\end{array}$ \\
\hline 25 & $\begin{array}{l}\text { Legal adjudication } \\
\text { platforms }\end{array}$ & $\mathrm{N}^{*}$ & $\begin{array}{l}\text { Conflict resolution mechanisms to support MPA governance and decision-making are needed. } \\
\text { However, due to weak state capacity and endemic governance issues, Vietnam is not ready to } \\
\text { implement this yet. }\end{array}$ \\
\hline 26 & $\begin{array}{l}\text { Transparency, } \\
\text { accountability and } \\
\text { fairness }\end{array}$ & $\mathrm{N}^{*}$ & $\begin{array}{l}\text { A severe lack of transparency in the governance of CNDP (in managing user fee, enforcement, } \\
\text { prosecution, the availability of biodiversity and coral reef assessment findings, etc) has } \\
\text { undermined trust and capacity for cooperation, and potentially leads to inappropriate 'rent- } \\
\text { seeking'. }\end{array}$ \\
\hline \multicolumn{4}{|c|}{ Participative } \\
\hline 27 & Rules for participation & $\mathrm{Y}^{*}$ & $\begin{array}{l}\text { CDNP follows a circular of the Ministry of Finance - which calls for community participation in } \\
\text { detecting and reporting violations and defines different levels of financial rewards to reporters } \\
\text { [50]. CD-DPC has also identified rules for the participation of representatives from fishing and } \\
\text { tourism sectors in the enforcement of MPA regulations with state agencies (FRSU, park rangers } \\
\text { and the border guard) [54]. However, the implementation of these rules rarely happens because of } \\
\text { inadequate financial support for participation and the participation of grass-root people in local } \\
\text { decision-making is critically influenced by mass organisations. Thus, the legal framework governing } \\
\text { should include clear rules for the meaningful participation of local people in local decision-making. }\end{array}$ \\
\hline 28 & $\begin{array}{l}\text { Establishing } \\
\text { collaborative } \\
\text { platforms }\end{array}$ & $\mathrm{Y}^{*}$ & $\begin{array}{l}\text { Under the UNDP/GEF project, several collaborative platforms, including the Community } \\
\text { Consultation Group (CCG) (comprising representatives from local communities, mass organisations } \\
\text { and local authorities) and a Conservation Trust Fund, were established [45]. The project also } \\
\text { encouraged local fishers to participate in coral reef surveys and rehabilitation programmes. } \\
\text { However, these structures are weakly maintained as the specific funding for this has ended. } \\
\text { Furthermore, a participative MPA management plan, which was legally acknowledged by CD-DPC } \\
\text { in 2008, was rejected by BRVT-PPC due to its incompatability with Vietnam's institutional context } \\
\text { of Vietnam that is more focused on political stability and rapid economic development. Recent } \\
\text { changes in the park's leadership have also weakened the collaboration between an international } \\
\text { dive operator and CDNP in the instalment and maintenance of mooring buoys and reporting } \\
\text { violations. }\end{array}$ \\
\hline 31 & $\begin{array}{l}\text { Decentralising } \\
\text { responsibilities }\end{array}$ & $\mathrm{Y}$ & $\begin{array}{l}\text { Some management responsibilities were decentralised to BRVT-PPC. Following the national trend } \\
\text { of decentralising state management responsibilities to district-level governments, CD-DPC has } \\
\text { recently proposed to take over CDNP from BRVT-PPC to boost local development. Given the } \\
\text { current weaknesses in governing CNDP and the reluctance of CD-DPC in coordination and } \\
\text { prosecuting transgressors, this incentive needs to be reinforced by more oversight from the central } \\
\text { government. }\end{array}$ \\
\hline 32 & Peer enforcement & $\mathrm{Y}^{*}$ & $\begin{array}{l}\text { The UNDP/GEF project promoted peer enforcement by local fishers. Also, rules for participation } \\
\text { mentioned above have promoted the participation of Con Dao communities, including divers, } \\
\text { tourism operators, and fishers in peer enforcement. This mechanism was financially supported by } \\
\text { the Conservation Trust Fund and state funding. However, the slow response from CDNP Authority, } \\
\text { dwindling of funding and lack of transparency in handling of reports have undermined this } \\
\text { incentive. }\end{array}$ \\
\hline 33 & $\begin{array}{l}\text { Building trust and the } \\
\text { capacity for } \\
\text { cooperation }\end{array}$ & $\mathrm{Y}^{*}$ & $\begin{array}{l}\text { Trust, which was built under the former park's leadership, has been eroded in recent years. } \\
\text { Consequently, many users, especially international dive instructors, continuously complain about } \\
\text { the park authority not doing their job in promoting effective marine conservation. In contrast, local } \\
\text { people, who either engage in fishing or tourism operation in CDNP, have been enjoying the state of } \\
\text { the loosely controlled access caused by the lack of leadership. }\end{array}$ \\
\hline 34 & $\begin{array}{l}\text { Building linkages } \\
\text { between relevant } \\
\text { authorities and user } \\
\text { representatives }\end{array}$ & $\mathrm{Y}^{*}$ & $\begin{array}{l}\text { Tensions between CDNP or and CD-DPC have resulted in weak 'cross-jurisdictional coordination' } \\
\text { and challenged the formation of linkages between CDNP Authority and local user groups. } \\
\text { Although, under the UNDP/GEF project, personal links between park rangers and beneficiaries of } \\
\text { AIG activities were developed through community consultation meetings and raising-awareness } \\
\text { sessions, such links weaken rather than brace the governance framework because rangers tend to } \\
\text { ignore violations of the NTZ regulations made by these individuals. Strengthening 'cross- } \\
\text { jurisdictional coordination', 'rules for participation' and 'peer enforcement' might be beneficial for } \\
\text { building positive linkages. The leadership role of BRVT-PPC is instrumental in resolving the conflicts } \\
\text { between CNDP Authority and CD-DPC, and thereby, fostering positive linkages between CDNP and } \\
\text { local user groups. }\end{array}$ \\
\hline 36 & $\begin{array}{l}\text { Potential to influence } \\
\text { higher institutional } \\
\text { levels }\end{array}$ & $\mathrm{Y}^{*}$ & $\begin{array}{l}\text { The park's former leadership had the capacity to influence the provincial government regarding } \\
\text { the park's organization, staffing and funding for conservation activities. Community protest against } \\
\text { the park's management, is indicative of the potential to influence decision-making at higher } \\
\text { government levels, though such influence has undermined the achievement of conservation } \\
\text { objectives. At present, sustaining positive linkages between CDNP and local user groups is } \\
\text { necessary to enable CDNP's influence on the decisions taken at higher government levels that } \\
\text { could serve to strengthen several governance incentives. This could be gained through increasing } \\
\text { the involvement of local people and user groups in governing CDNP provided that they are well } \\
\text { aware of the need for protecting local resources and of related conservation } \\
\text { objectives/obligations. }\end{array}$ \\
\hline
\end{tabular}

